Policy Research Working Paper 7212

\title{
Economic Implications of a Potential Free Trade Agreement between India and the United States
}

\author{
Emiko Fukase \\ Will Martin
}


Policy Research Working Paper 7212

\begin{abstract}
This paper explores the economic implications of a potential free trade agreement between India and the United States. A series of simulations is conducted assuming 100 percent ad valorem equivalent tariff cuts for goods and 50 percent cuts for services. The overall impacts are likely to be positive for the United States and India. While gains from trade creation are offset by trade diversion on the import side, both countries appear to gain from improved access on the export side. The United States is likely to gain largely through terms of trade improvements for its goods and services, as initial protection in India is particularly high. India would experience an expansion of exports and output, especially in textiles and apparel. As the United
\end{abstract}

States and India are negotiating other free trade agreements, such as the Trans-Pacific Partnership and India's agreement with the Association of Southeast Asian Nations, the paper also explores how the effects of an India-United States free trade agreement are affected by prior free trade agreements. Adding an India-United States free trade agreement to prior agreements tends to bring additional welfare benefits to both countries. India would also gain substantially if it concluded a free trade agreement with the United States and then extended it to other partners. The results suggest that an India-United States free trade agreement might become a building block toward more liberal trade regimes.

This paper is a product of the Agriculture and Rural Development Team, Development Research Group. It is part of a larger effort by the World Bank to provide open access to its research and make a contribution to development policy discussions around the world. Policy Research Working Papers are also posted on the Web at http://econ.worldbank.org. The authors may be contacted at efukase@worldbank.org orwmartin1@worldbank.org.

The Policy Research Working Paper Series disseminates the findings of work in progress to encourage the exchange of ideas about development issues. An objective of the series is to get the findings out quickly, even if the presentations are less than fully polished. The papers carry the names of the authors and should be cited accordingly. The findings, interpretations, and conclusions expressed in this paper are entirely those of the authors. They do not necessarily represent the views of the International Bank for Reconstruction and Development/World Bank and its affliated organizations, or those of the Executive Directors of the World Bank or the governments they represent. 


\title{
Economic Implications of a Potential Free Trade Agreement between India and the United States
}

\author{
Emiko Fukase and Will Martin
}

JEL Codes: F13, F15, F17

Keywords: free trade agreement, India, United States, CGE

* We would like to thank Arvind Subramanian and Fred Bergsten for the opportunity to prepare this paper and for guidance on its design; Aaditya Mattoo for advice; and the participants in a meeting at the Peterson Institute for International Economics, particularly our discussant Peter Petri, for very useful comments and suggestions. 


\section{Introduction}

A potential Free Trade Agreement (FTA) between India and the United States presents a number of opportunities and may bring economic benefits to both countries. While India has substantially liberalized its trade and investment regime since its economic reform, which started in 1991, it remains a relatively highly protected economy. For India, deeper economic ties with the United States may provide opportunities to continue its own economic reform; to benefit from advanced and efficient technologies through trade and investment; to improve access to the large U.S. market, particularly for India's labor-intensive goods; and to create defenses against the U.S.'s protectionist pressure, especially for its growing service exports. For the United States, after having concluded successfully a number of FTAs since the 1990s, negotiating one with India may be a logical path in pursuing further its economic interests. In particular, the U.S. may expect to improve its access to the fast growing Indian market, including for those parts of the service sector in which the U.S. is likely to have a comparative advantage.

However, many economists are skeptical about using FTAs as a way to advance trade reforms, arguing that regional or bilateral trade agreements result in discriminatory liberalization, which in turn is said to cause FTA member economies to suffer from trade diversion. The uncertainty about the implications of an India-US FTA is increased by the fact the United States and India are negotiating other FTAs such as the US-EU agreement ${ }^{1}$, the Trans-Pacific Partnership (TPP), and India's agreement with the Association of Southeast Asian Nations (ASEAN). A key feature of an FTA is that countries reduce barriers on a "reciprocal" basis, so negotiations require FTA parties to agree to reduce their own barriers while winning concessions from their trading partner(s). Thus, the economic impacts resulting from an FTA need to be

\footnotetext{
${ }^{1}$ More formally known as the Trans-Atlantic Trade and Investment Partnership (TTIP).
} 
evaluated for both imports and exports, addressing such issues as trade creation and trade diversion consequences and gains resulting from access to partners' markets.

The objective of this paper is to provide a preliminary assessment of the potential economic impacts of an FTA between India and the United States. For this, we use the Global Trade Analysis Project (GTAP) model (Hertel 1996) (Version 8). ${ }^{2}$ GTAP is a relatively standard applied Computable General Equilibrium (CGE) model which is used for a variety of applications, including for studies to evaluate, ex ante, the welfare impacts of FTAs (Hertel, Hummels, Ivanic and Roman, 2007). To ensure maximum clarity and transparency, the analysis is intentionally simple and "static" in order to address key issues such as the nature and extent of trade creation and diversion from an agreement, and the sensitivity of these effects to the presence of other preferential trade agreements.

There are two major limitations to this study. Because of our focus on simplicity and transparency, the paper does not take into account "dynamic" impacts of an FTA such as the impacts of the increased foreign direct investment (FDI) inflow, positive impacts on productivity growth resulting from access to foreign knowledge, and accelerated domestic reforms (Fukase and Winters, 2003). For the same reason, we use standard trade-weighted averages of protection, rather than the more sophisticated optimal aggregation approach outlined in Laborde, Martin and Van der Mensbrugghe (2011). Since the nature of liberalization to be undertaken is not clear at this stage, the simulation scenarios are based on a uniform assumption, i.e. 100 percent Ad Valorem Equivalent (AVE) tariff cuts for goods and 50 percent cuts for services. We use the smaller reduction in barriers on services trade because many of these barriers are qualitative and difficult to distinguish from non-discriminatory liberalization. In sum, the main focus of the

\footnotetext{
${ }^{2}$ The base year for GTAP 8 is 2007.
} 
paper is to illustrate mechanisms through which an FTA might cause welfare changes, rather than providing a precise estimate of the aggregate impacts.

Following this introduction, Section II examines the underlying patterns of trade and protection in each country. Section III illustrates theories of preferential trade liberalization. Section IV conducts a series of simulations. We first evaluate the potential impacts of an IndiaUS FTA on trade, output and welfare for both countries. Then we investigate how the economic implications of an India-US FTA vary depending on prior agreements. Section V presents a brief conclusion.

\section{Section II. Recent Trends in Trade and Protection Patterns}

\section{General Trends}

Figures $1 \mathrm{a}$ and $1 \mathrm{~b}$ show that trade between India and the United States has been growing rapidly. U.S. imports from India rose from $\$ 13$ billion to $\$ 54$ billion during the period 2000-2011, while U.S. exports to India increased from $\$ 6$ billion to $\$ 32$ billion. Trade in services is especially important in both directions. In particular, exports of services from India to the U.S. have increased dramatically since around 2005. Trade in manufactures appears to be growing steadily. Trade in agriculture (including processed agriculture) is relatively small in both directions. Throughout the period, the United States has experienced an overall trade deficit relative to India. The U.S. had a trade surplus with India in the services sector until 2005, and a trade deficit since 2006.

\section{Trade and Protection Patterns}

The economic implications of an FTA between India and the United States will depend heavily upon the pattern of trade between these two countries and on their patterns of protection. The patterns of their protection and trade flows will in turn influence the extent of gains and losses 
due to terms-of-trade effects and the benefits and costs accruing from trade creation and diversion. Figures $2 \mathrm{a}$ and $2 \mathrm{~b}$ show the sources and destinations of US imports and exports by its trading partners for the year 2007 constructed from the GTAP 8 database. The figures show that India accounts for around 2 percent of US imports and exports. The U.S.'s North American Free Trade Agreement (NAFTA) partners, namely Canada and Mexico combined, are the largest sources and destinations of U.S. trade flows (representing 24 percent of imports and 26 percent of exports), followed by the 27 member European Union (EU) in both directions (21 percent of US imports and 25 percent of exports). Figures $3 \mathrm{a}$ and $3 \mathrm{~b}$ show that the U.S. is much more important as a trading partner for India, accounting for 9 percent of imports and 18 percent of exports, respectively. The EU is the most important import source and export destination for India, accounting for 20 percent and 29 percent of India's imports and exports, respectively. 


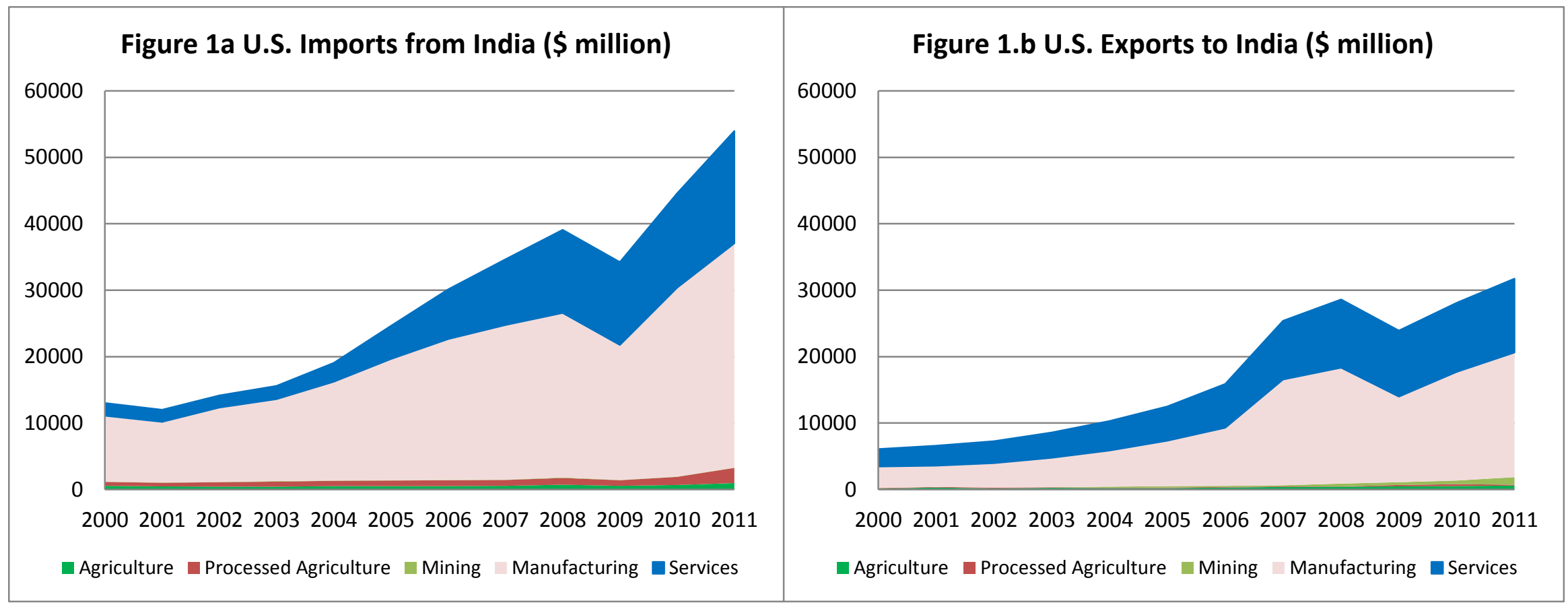

\begin{tabular}{|c|c|c|c|c|c|c|c|c|c|c|c|c|}
\hline \multicolumn{13}{|c|}{ U.S. Imports from India (\$ million) } \\
\hline & $\underline{2000}$ & 2001 & 2002 & 2003 & 2004 & $\underline{2005}$ & 2006 & 2007 & 2008 & 2009 & $\underline{2010}$ & $\underline{2011}$ \\
\hline Agriculture & $\overline{548}$ & $\overline{445}$ & $\overline{413}$ & $\overline{406}$ & $\overline{491}$ & $\overline{516}$ & $\overline{517}$ & $\overline{562}$ & $\overline{699}$ & $\overline{554}$ & $\overline{657}$ & $\overline{972}$ \\
\hline Processed Agriculture & 596 & 573 & 688 & 760 & 804 & 817 & 853 & 860 & 1046 & 852 & 1252 & 2277 \\
\hline Mining & 27 & 38 & 25 & 77 & 57 & 74 & 80 & 44 & 85 & 31 & 47 & 50 \\
\hline Manufacturing & 9941 & 9109 & 11199 & 12351 & 14880 & 18243 & 21214 & 23307 & 24762 & 20303 & 28428 & 33747 \\
\hline Services & 1901 & 1821 & 1817 & 1985 & 2844 & 4985 & 7460 & 9883 & 12498 & 12486 & 14188 & 16921 \\
\hline Total & 13013 & 11986 & 14142 & 15580 & 19076 & 24635 & 30124 & 34656 & 39091 & 34226 & 44572 & 53967 \\
\hline \multicolumn{13}{|c|}{ U.S. Exports to India (\$ million) } \\
\hline & $\underline{2000}$ & 2001 & 2002 & 2003 & $\underline{2004}$ & $\underline{2005}$ & $\underline{2006}$ & 2007 & $\underline{2008}$ & $\underline{2009}$ & $\underline{2010}$ & $\underline{2011}$ \\
\hline Agriculture & 119 & 284 & 180 & 256 & 189 & 225 & 287 & 386 & 406 & 473 & 490 & 585 \\
\hline Processed Agriculture & 97 & 72 & 96 & 61 & 65 & 70 & 74 & 79 & 73 & 197 & 306 & 144 \\
\hline Mining & 43 & 26 & 34 & 30 & 145 & 191 & 177 & 142 & 406 & 414 & 569 & 1141 \\
\hline Manufacturing & 3221 & 3203 & 3668 & 4435 & 5460 & 6865 & 8765 & 15934 & 17437 & 12904 & 16335 & 18752 \\
\hline Services & 2580 & 3016 & 3270 & 3776 & 4464 & 5137 & 6587 & 8851 & 10267 & 9945 & 10382 & 11108 \\
\hline Total & 6060 & 6601 & 7248 & 8558 & 10323 & 12488 & 15891 & 25392 & 28587 & 23933 & 28083 & 31730 \\
\hline
\end{tabular}

Sources: The UN Comtrade System for the goods data; Bureau of Economic Analysis for the services data, www.bea.gov. 


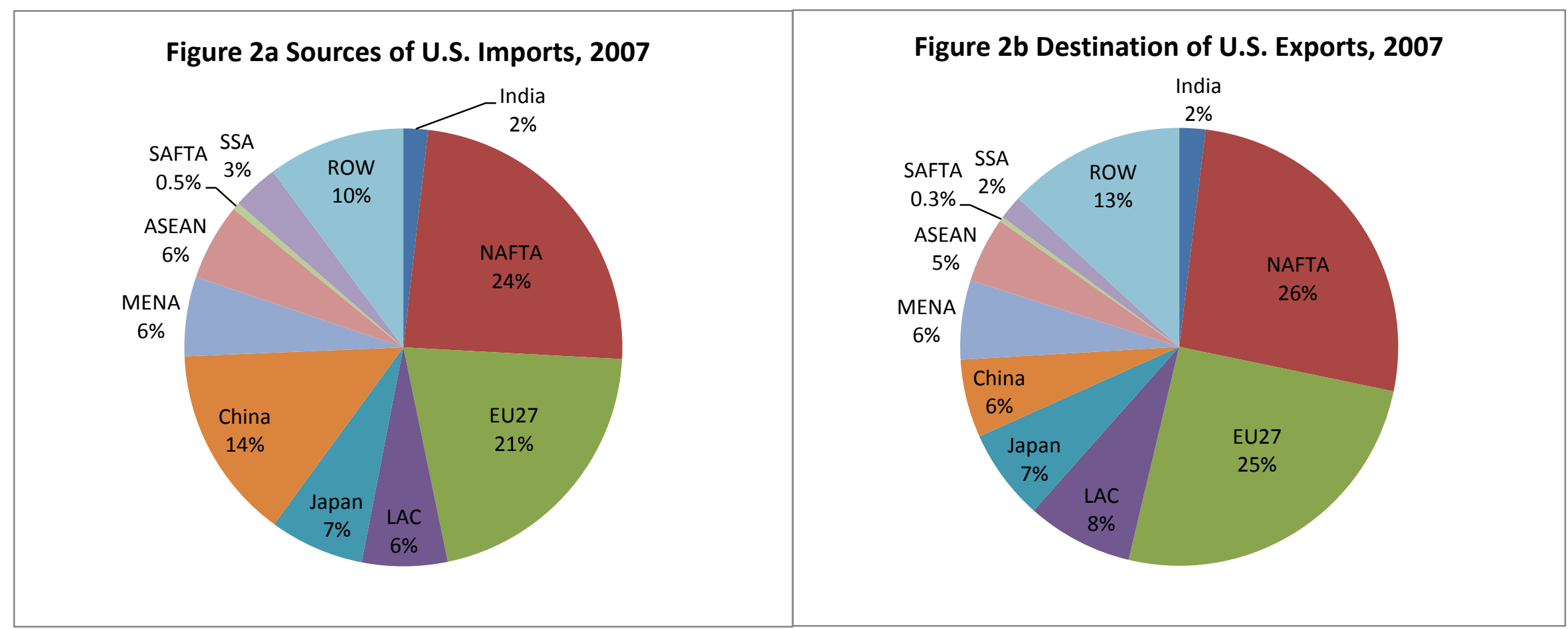

ASEAN = Association of South East Asian Nations, EU $=$ European Union, LAC $=$ Latin America and the Caribbean, MENA = Middle East and North Africa, SA = South Asia, SSA = Sub-Saharan Africa, NAFTA = North American Free Trade Agreement, SAFTA = South Asian Free Trade Area.

Source: GTAP 8 Database.

Notes: NAFTA share consists of Canada and Mexico and does not include the United States. SAFTA share does not include India. 


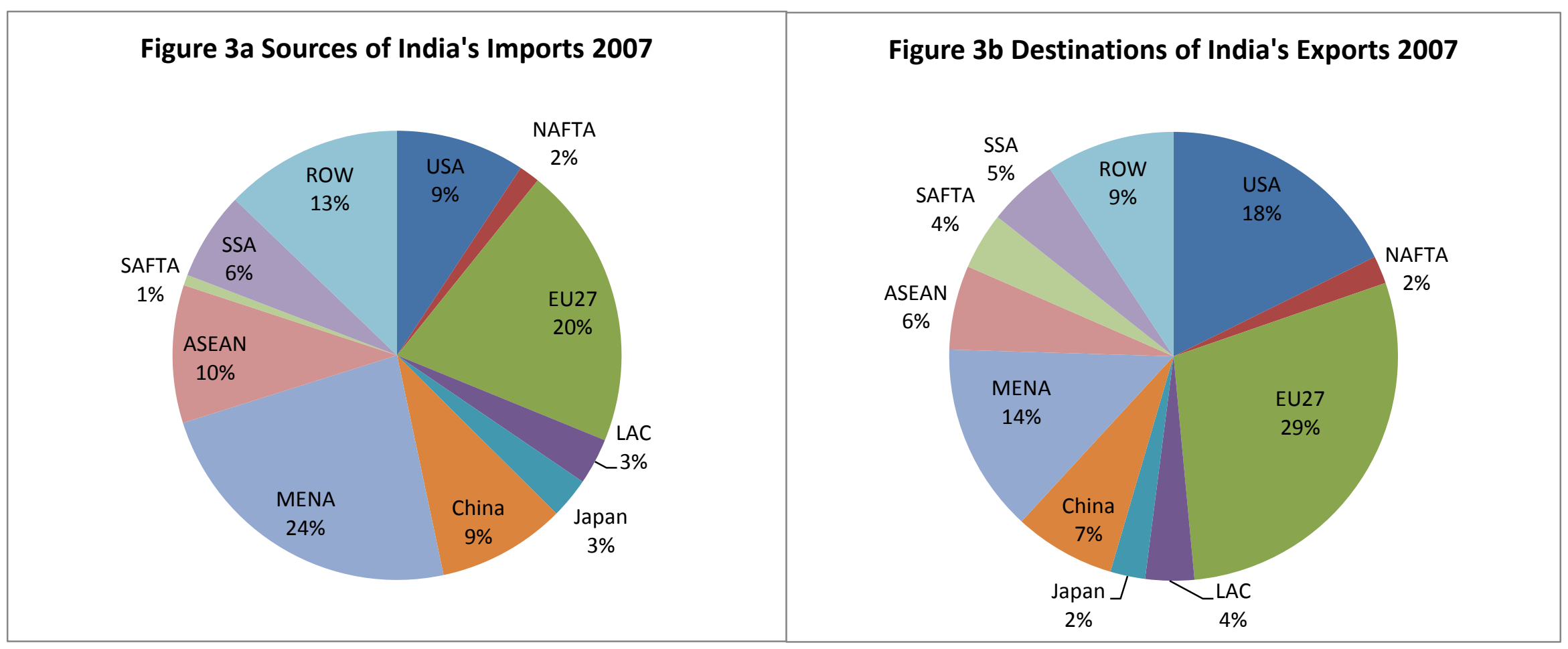

ASEAN = Association of South East Asian Nations, EU $=$ European Union, LAC $=$ Latin America and the Caribbean, MENA = Middle East and North Africa, SA = South Asia, SSA = Sub-Saharan Africa, NAFTA = North American Free Trade Agreement, SAFTA = South Asian Free Trade Area.

Source: GTAP 8 Database.

Notes: NAFTA share consists of Canada and Mexico and does not include the United States. SAFTA share does not include India. 
Table 1 presents the Trade Intensity Index (TII) (Drysdale and Garnaut 1982), which indicates whether the value of trade between two countries is greater or smaller than would be expected given their relative importance in world trade by the sectors used in the analysis. ${ }^{3}$ Despite the crudity of this measure-it does not take into consideration factors such as transport cost and other characteristics - the index gives some preliminary indication as to how trade (both imports and exports) of both partners may be reduced by the presence of trade barriers. A value of TII greater than one suggests that country $i$ exports to county $j$ more than would be expected and vice versa.

Specifically, $\mathrm{TII}_{\mathrm{ij}}=\left[\mathrm{X}_{\mathrm{ij}} / \mathrm{X}_{\mathrm{i}}\right] /\left[\mathrm{M}_{\mathrm{j}} /\left(\mathrm{M}_{\mathrm{w}}-\mathrm{M}_{\mathrm{i}}\right)\right]$

Where $\mathrm{X}_{\mathrm{ij}}$ is country $i$ 's exports to country $j$

$\mathrm{X}_{\mathrm{i}}$ is $i$ 's total exports

$\mathrm{M}_{\mathrm{j}}$ is $j$ 's total imports

$\mathrm{M}_{\mathrm{i}}$ is $i$ 's total imports, and

$\mathrm{M}_{\mathrm{w}}$ is total world imports

$\mathrm{M}_{\mathrm{i}}$ is subtracted from $\mathrm{M}_{\mathrm{w}}$ because a country cannot export goods to itself.

\footnotetext{
3 Throughout the paper, the 57 GTAP sectors are aggregated into 13 more manageable categories. Agriculture ("paddy rice", "wheat", "other grains", "veg \& fruit", "oil seeds", "cane \& beet", "plant fibres", "other crops", "cattle", "other animal products", "raw milk", "wool", "forestry" and "fishing"); Processed agriculture ("cattle meat", "other meat", "vegetable oils", "milk", "processed rice", "sugar", "other food" and "beverages \& tobacco"); Coal, oil, gas and other mining ("coal", "oil", "gas" and "other mining"); Textiles and apparel ("textiles" and "wearing apparel"); Other light manufacturing ("leather" and "lumber"); Paper and mineral products ("paper \& paper products" and "non-metallic minerals"); Chemical, rubber and plastic products ("chemical \& rubber products"); Petroleum and coke products ("petroleum \& coke"); Iron, steel and metal products ("iron \& steel", "nonferrous metals" and "fabricated metal products"); Transport Equipment ("motor vehicles" and "other transport equipment"); Electronics and machinery ("electronic equipment" and "other machinery \& equipment"); Other manufacturing ("other manufacturing"); and Services ("electricity", "gas distribution", "water", "construction", "trade", "water transport", "air transport", "other transport", "communications", "other financial intermediation", "insurance", "other business services", "recreation \& other services", "other services (government)" and "dwellings"). Between parentheses are the original GTAP sectors available in the GTAP 8 database.
} 
Table 1 Trade intensity indexes for the U.S. and India, 2007

\begin{tabular}{|c|c|c|}
\hline & $\begin{array}{c}\mathrm{i}=\text { US } \\
\mathrm{j}=\text { India }\end{array}$ & $\begin{array}{c}\mathrm{i}=\text { India } \\
\mathrm{j}=\mathrm{US}\end{array}$ \\
\hline Agriculture & 0.5 & 1.0 \\
\hline Processed agriculture & 0.3 & 0.8 \\
\hline Coal, oil, gas and other mining & 0.1 & 0.0 \\
\hline Textiles and apparel & 0.9 & 1.4 \\
\hline Other light manufacturing & 0.7 & 0.6 \\
\hline Paper and mineral products & 1.1 & 1.8 \\
\hline Chemical, rubber and plastic products & 0.9 & 1.2 \\
\hline Iron, steel and metal products & 0.6 & 0.9 \\
\hline Petroleum and coke products & 0.3 & 0.5 \\
\hline Transport equipment & 2.8 & 0.6 \\
\hline Electronics and machinery & 0.7 & 1.2 \\
\hline Other manufacturing & 1.6 & 1.1 \\
\hline Services & 1.3 & 2.0 \\
\hline Total & 0.9 & 1.2 \\
\hline
\end{tabular}

Table 1 reveals several features of India-US trade patterns. The first is that US exports to India are smaller than would be expected given India's share in world trade, while India's exports to the United States are greater than would be expected. Within US exports, the trade intensities are particularly low for agricultural goods ( 0.5 for agriculture and 0.3 for processed agriculture) and for the products of the mining sector (0.1). Exports of transport equipment and services from the US to India are disproportionately large, with trade intensities of $2.8^{4}$ and 1.3 , respectively. Within India's exports to the U.S., trade intensities are particularly low for mining sector products (0.0), and particularly high for services (2.0).

\footnotetext{
${ }^{4}$ This particularly high TII appears to reflect India's large purchases of transport equipment in 2007.
} 
Table 2a U.S. AVE protection against goods by suppliers, 2007 (percent)

Agriculture

Processed agriculture

India US NAFTA EU27 LAC Japan China MENA ASEAN

Coal, oil, gas and other mining

Textiles and apparel

Other light manufacturing

Paper and mineral products

Chemical, rubber and plastic products

Iron, steel and metal products

Petroleum and coke products

Transport equipment

Electronics and machinery

1.0 n.a. 0.3

$\begin{array}{llll}3.7 & 2.5 & 1.4 & 1.3\end{array}$

$\begin{array}{lll}2.2 & \text { n.a. } & 2.0 \\ 0.0 & \text { n.a. } & 0.0 \\ 9.1 & \text { n.a. } & 0.0\end{array}$

9.1 n.a. 0.0

$\begin{array}{llll}3.3 & 3.9 & 4.0 & 3.5\end{array}$

0.9

$\begin{array}{llll}0.0 & 0.0 & 0.0 & 0.2\end{array}$

3.8 n.a. 0.0

1.5 n.a. 0.0

$8.2 \quad 3.9$

$\begin{array}{lll}1.5 & \text { n.a. } & 0.0\end{array}$

0.1 n.a. 0.0

$3.1 \quad 1.7$

$2.6 \quad 1.4$

6.3

2.6

$\begin{array}{lll}1.2 & 0.4 & 1.9\end{array}$

$\begin{array}{lll}0.1 & \text { n.a. } & 0.0 \\ 0.7 & \text { n.a. } & 0.0\end{array}$

$\begin{array}{lll}1.3 & 0.3 & 1.7\end{array}$

0.0 n.a. 0.0

$\begin{array}{lll}1.3 & 0.5 & 1.1\end{array}$

$0.9 \quad 0.2 \quad 1.2$

0.2 n.a. 0.0

$0.8 \quad 0.1$

$\begin{array}{lll}0.0 & \text { n.a. } & 0.0 \\ 2.7 & \text { n.a. } & 0.1\end{array}$

1.3

Other

Table 2b India AVE protection against goods by suppliers, 2007 (percent)

\begin{tabular}{|c|c|c|c|c|c|c|c|c|c|c|c|c|c|}
\hline & India & $\underline{\text { US }}$ & NAFTA & $\underline{E U 27}$ & $\underline{\text { LAC }}$ & Japan & China & MENA & ASEAN & $\underline{\text { SAFTA }}$ & $\underline{\text { SSA }}$ & $\underline{\text { ROW }}$ & $\underline{\text { Total }}$ \\
\hline Agriculture & n.a. & 26.5 & 56.0 & 32.1 & 44.3 & 13.7 & 33.6 & 19.8 & 20.6 & 25.5 & 23.4 & 59.4 & 33.9 \\
\hline Processed agriculture & n.a. & 54.1 & 72.4 & 90.1 & 50.5 & 42.4 & 37.1 & 52.4 & 97.6 & 14.4 & 50.4 & 55.4 & 78.8 \\
\hline Coal, oil, gas and other mining & n.a. & 13.1 & 9.4 & 12.7 & 5.7 & 13.1 & 15.3 & 10.1 & 11.0 & 9.9 & 10.0 & 18.2 & 10.6 \\
\hline Textiles and apparel & n.a. & 15.0 & 15.9 & 15.4 & 14.6 & 15.0 & 17.0 & 15.3 & 15.0 & 10.2 & 15.5 & 15.3 & 15.8 \\
\hline Other light manufacturing & n.a. & 14.8 & 14.7 & 14.3 & 11.4 & 14.8 & 14.9 & 11.8 & 13.9 & 5.8 & 10.8 & 12.8 & 13.4 \\
\hline Paper and mineral products & n.a. & 13.7 & 11.6 & 14.4 & 13.6 & 15.1 & 14.3 & 14.9 & 13.0 & 5.1 & 13.3 & 14.6 & 13.8 \\
\hline Chemical, rubber and plastic products & n.a. & 10.8 & 13.6 & 14.8 & 15.2 & 14.5 & 14.3 & 12.8 & 15.6 & 6.3 & 15.4 & 14.1 & 13.8 \\
\hline Iron, steel and metal products & n.a. & 16.8 & 17.5 & 16.9 & 18.8 & 18.2 & 16.4 & 15.5 & 16.8 & 9.8 & 15.3 & 15.5 & 16.0 \\
\hline Petroleum and coke products & n.a. & 15.0 & 13.9 & 14.8 & 11.2 & 15.0 & 15.0 & 13.6 & 13.3 & 14.1 & 13.3 & 14.5 & 13.8 \\
\hline Transport equipment & n.a. & 4.9 & 13.0 & 11.2 & 12.1 & 29.9 & 15.4 & 12.3 & 17.8 & 2.0 & 25.5 & 16.1 & 10.4 \\
\hline Electronics and machinery & n.a. & 9.7 & 8.3 & 12.3 & 12.7 & 13.2 & 7.6 & 7.2 & 6.5 & 2.8 & 10.0 & 11.4 & 9.9 \\
\hline Other manufacturing & n.a. & 15.0 & 15.2 & 15.1 & 11.5 & 15.1 & 13.7 & 15.0 & 13.6 & 6.5 & 14.0 & 15.0 & 14.8 \\
\hline Total & n.a. & 9.9 & 19.4 & 13.8 & 12.3 & 16.3 & 11.7 & 11.2 & 23.3 & 12.1 & 11.5 & 16.5 & 13.8 \\
\hline
\end{tabular}

Source: GTAP 8 Database.

Notes: n.a. $=$ not applicable. 
Table 3a AVE protection that U.S. goods exports face by destinations, 2007 (percent)

\begin{tabular}{|c|c|c|c|c|c|c|c|c|c|c|c|c|c|}
\hline & India & $\underline{\text { US }}$ & NAFTA & EU27 & $\underline{\mathrm{LAC}}$ & Japan & China & MENA & ASEAN & SAFTA & SSA & ROW & Total \\
\hline Agriculture & $\overline{26.5}$ & $\overline{\text { n.a. }}$ & 3.3 & 3.7 & $\overline{10.2}$ & 13.3 & 11.3 & 5.3 & 5.1 & 5.7 & $\overline{5.1}$ & $\overline{67.8}$ & $\overline{16.4}$ \\
\hline Processed agriculture & 54.1 & n.a. & 11.0 & 14.6 & 13.0 & 30.0 & 10.5 & 17.6 & 9.3 & 17.0 & 17.2 & 20.1 & 15.7 \\
\hline Coal, oil, gas and other mining & 13.1 & n.a. & 0.0 & 0.0 & 1.6 & 0.0 & 0.7 & 1.1 & 1.7 & 5.4 & 3.4 & 0.5 & 0.3 \\
\hline Textiles and apparel & 15.0 & n.a. & 0.0 & 7.6 & 8.1 & 7.0 & 8.5 & 5.4 & 8.1 & 9.3 & 19.2 & 6.9 & 4.6 \\
\hline Other light manufacturing & 14.8 & n.a. & 0.0 & 2.2 & 13.4 & 3.8 & 4.0 & 6.1 & 5.2 & 15.5 & 15.5 & 3.8 & 2.7 \\
\hline Paper and mineral products & 13.7 & n.a. & 0.0 & 1.0 & 7.8 & 0.2 & 2.6 & 4.6 & 4.4 & 10.4 & 8.0 & 2.1 & 1.8 \\
\hline Chemical, rubber and plastic products & 10.8 & n.a. & 0.0 & 2.3 & 7.4 & 1.5 & 142.5 & 4.4 & 3.5 & 8.7 & 5.3 & 3.2 & 11.9 \\
\hline Iron, steel and metal products & 16.8 & n.a. & 0.0 & 1.6 & 9.8 & 0.9 & 4.2 & 3.8 & 3.0 & 10.0 & 8.8 & 1.0 & 1.8 \\
\hline Petroleum and coke products & 15.0 & n.a. & 0.0 & 1.9 & 5.0 & 0.2 & 6.0 & 2.6 & 1.8 & 13.9 & 7.3 & 2.3 & 2.4 \\
\hline Transport equipment & 4.9 & n.a. & 0.0 & 3.3 & 8.3 & 0.0 & 6.8 & 3.0 & 3.0 & 7.7 & 9.4 & 4.0 & 2.4 \\
\hline Electronics and machinery & 9.7 & n.a. & 0.0 & 1.1 & 6.8 & 0.1 & 3.3 & 3.8 & 0.9 & 8.6 & 4.3 & 2.3 & 2.0 \\
\hline Other manufacturing & 15.0 & n.a. & 0.0 & 1.2 & 14.3 & 1.7 & 13.0 & 2.4 & 78.9 & 10.8 & 15.4 & 5.1 & 5.7 \\
\hline Total & 9.9 & n.a. & 0.7 & 2.3 & 7.6 & 5.0 & 29.8 & 4.3 & 3.3 & 8.5 & 7.2 & 7.9 & 5.3 \\
\hline
\end{tabular}

Table 3b AVE protection that Indian goods exports face by destinations, 2007 (percent)

\begin{tabular}{|c|c|c|c|c|c|c|c|c|c|c|c|c|c|}
\hline & India & $\underline{U S}$ & NAFTA & $\underline{E U 27}$ & $\underline{\mathrm{LAC}}$ & Japan & China & MENA & ASEAN & SAFTA & $\underline{\text { SSA }}$ & $\underline{\text { ROW }}$ & $\underline{\text { Total }}$ \\
\hline Agriculture & n.a. & 1.0 & 3.3 & 3.0 & 11.0 & 3.2 & 36.8 & 6.8 & 8.4 & 11.2 & 10.5 & 27.6 & 12.6 \\
\hline Processed agriculture & n.a. & 2.2 & 5.7 & 10.9 & 11.5 & 3.2 & 9.7 & 7.0 & 6.6 & 10.9 & 14.6 & 11.6 & 8.6 \\
\hline Coal, oil, gas and other mining & n.a. & 0.0 & 4.2 & 0.0 & 2.5 & 0.2 & 0.1 & 2.4 & 2.5 & 8.3 & 5.2 & 0.2 & 0.3 \\
\hline Textiles and apparel & n.a. & 9.1 & 16.9 & 7.9 & 13.6 & 5.4 & 5.3 & 9.5 & 9.2 & 8.8 & 18.3 & 7.4 & 9.2 \\
\hline Other light manufacturing & n.a. & 3.8 & 8.6 & 2.2 & 11.6 & 12.8 & 5.9 & 8.8 & 4.4 & 14.6 & 17.5 & 4.3 & 3.8 \\
\hline Paper and mineral products & n.a. & 1.5 & 5.2 & 0.5 & 8.8 & 0.0 & 4.5 & 5.9 & 6.6 & 15.2 & 12.7 & 3.8 & 4.5 \\
\hline Chemical, rubber and plastic products & n.a. & 0.7 & 3.6 & 0.5 & 7.0 & 0.1 & 5.5 & 6.3 & 2.7 & 7.8 & 6.8 & 3.4 & 3.6 \\
\hline Iron, steel and metal products & n.a. & 0.1 & 4.4 & 0.3 & 8.1 & 0.9 & 3.2 & 3.2 & 3.9 & 6.1 & 13.2 & 2.2 & 3.0 \\
\hline Petroleum and coke products & n.a. & 0.7 & 7.1 & 0.0 & 0.8 & 0.5 & 5.8 & 7.6 & 3.0 & 13.7 & 7.8 & 3.2 & 4.7 \\
\hline Transport equipment & n.a. & 0.0 & 24.0 & 2.4 & 16.4 & 0.0 & 8.3 & 7.9 & 17.1 & 14.8 & 7.7 & 4.6 & 7.1 \\
\hline Electronics and machinery & n.a. & 0.2 & 3.6 & 0.1 & 8.7 & 0.0 & 4.3 & 5.2 & 2.9 & 6.9 & 5.8 & 3.0 & 2.6 \\
\hline Other manufacturing & n.a. & 0.0 & 1.1 & 0.7 & 7.1 & 0.2 & 2.9 & 4.0 & 0.6 & 14.5 & 17.1 & 0.5 & 1.6 \\
\hline Total & n.a. & 2.7 & 8.9 & 3.0 & 6.5 & 1.2 & 3.9 & 5.6 & 4.5 & 10.9 & 10.1 & 4.8 & 4.8 \\
\hline
\end{tabular}

Source: GTAP 8 Database.

Notes: n.a. $=$ not applicable. 
The analysis of TII in table 1 suggests that current trade flows may partly reflect the prevailing trade distortions that influence these flows. Using the GTAP 8 database, Column 1 in table 2a shows the U.S.'s Ad Valorem Equivalent (AVE) tariff rates against India's goods, for which reductions would increase U.S. imports from India. The remaining columns of table $2 \mathrm{a}$ show the barriers which apply to other U.S. trading partners - these exports to the U.S. are likely to be reduced by an India-US FTA and the associated U.S. tariff revenues to be reduced, with consequent reductions in economic welfare.

An important feature of the GTAP 8 database is the use of protection data which include a comprehensive treatment of trade preferences resulting from preferential trade arrangements (PTAs) as well as the conversion of specific tariffs for both agricultural and non-agricultural goods (Guimbard, Jean, Mimouni and Pichot 2012). Overall, the average AVE rate of protection in the U.S. is relatively low at 1.3 percent. The variation of tariff rates by source countries reflects both preferential schemes and the composition of U.S. imports. The U.S. AVE protection against India's goods of 2.7 percent is higher than average and the U.S. retains particularly high barriers in the textile and clothing sector (9.1 percent). In contrast, the U.S. grants duty-free access to NAFTA partners for their apparel and textile products and applies substantially lower tariffs against the SSA region (0.5 percent) which reflects particularly the preferential rates under the African Growth and Opportunity Act (AGOA). As the US FTAs with Morocco, Chile, and Central America all allowed for immediate duty-free access to textile and apparel products meeting the agreements' rules of origin (Lawrence and Chadha 2004), a similar agreement with India - or, better, one that does not include restrictive rules of origin — would be likely to give Indian producers of textile and apparel products a competitive advantage in the US market. 
Table $2 \mathrm{~b}$ shows that India's AVE tariffs are generally high (13.8 percent on average), and are particularly high in the agricultural sectors against exports from all regions. India's AVE against US goods of 9.9 percent is lower than for India's other partners, while the tariffs against some of its trading partners are especially high, for instance, 23.3 percent against its ASEAN suppliers. This is particularly important because trade diversion is more likely to generate costs when the protection against imports from other partners exceeds that from the country for which import barriers are being reduced.

On the export side, the removal of barriers by a country's FTA partner is a key factor in reaping gains from reciprocal trade liberalization. The higher the initial barriers imposed by a country's trading partner, the larger the (potential) scope of improved market access resulting from an FTA, and the bigger the potential terms-of-trade gains to the exporter. Table $3 \mathrm{a}$ compares the AVE protection that US exporters encounter in the Indian market with the protection they face in other markets. Overall, US exports face on average a tariff of 5.3 percent across all export markets. The protection that US exporters face in the Indian market (9.9 percent) is nearly double the average. This structure of protection suggests that the U.S is likely to gain greatly from improved market access resulting from an India-US FTA. Similarly, table 3b compares the protection Indian exporters face in the US market and those in India's other export destinations. Indian exporters face on average 4.8 percent of protection globally against their exports of goods. Since US barriers against Indian exports (2.7 percent) are relatively low overall, India's terms of trade gains on the export side may be relatively small on averagealthough the potential volumes of trade are very large. On the other hand, since the U.S. is among India's leading export destinations (figure 3b) and the US tariff against Indian labor- 
intensive goods remains high, Indian market access to the U.S. is likely to remain an important issue in its negotiation.

Many economists believe that the potential gains from liberalization in the service sector may be larger than gains available from liberalization of the trade in goods (e.g., Gervais and Jensen 2013 for the United States; Konan and Maskus 2006 for Tunisia; Chadha, Brown, Deardorff and Stern 2000 for India). The scope for gains from services trade liberalization may be higher since barriers to trade in services tend to be higher than the remaining barriers to trade in goods. Moreover, it is increasingly recognized that service sector trade liberalization not only directly affects service production and trade, but also has positive impacts on productivity or exports of goods, especially in developing countries (Arnold, Javorcik, Lipscomb and Mattoo 2012; Cebula, Mazumdar and Nair-Reichert 2011; Fukui and McDaniel 2010; Konan and Maskus 2006; Robinson, Wang and Martin 2002).

Analysis of the impacts of services trade liberalization is severely constrained by the lack of reliable services trade and protection data. The estimates of services trade barriers vary widely in the literature, depending on methodologies, how the barriers are defined, which sectors are included and whether the barriers include non-discriminatory impediments or apply only against foreign suppliers. However, many economists generally view the services barriers in India to be high, and those in the U.S. to be low (e.g., Borchert, Gootiiz and Mattoo 2014; Gervais and Jensen 2013; Hufbauer, Schott and Wong 2010; Petri, Plummer, and Zhai 2012). ${ }^{5}$ As the best available educated guesstimate at the time of writing, we used the tariff equivalents of services

\footnotetext{
5 For instance, according to the Services Trade Restrictions Database which was released recently by the World Bank, India is found to be among the countries which have the most restrictive policies in services while service trade in the United States is found to be generally open (figure 4, Borchert et al.2014). The Services Trade Restrictions Indices (STRI), which range from 0 to 100, are found to be 17.7 and 65.7 for the U.S. and India respectively. However, the STRI does not cover cross-border trade in business processing services associated with the "outsourcing" phenomenon.
} 
barriers reported in Hufbauer, Schott and Wong (table B.2, 2010). According to these measures, the tariff equivalents of services barriers are estimated to be 6.03 percent for the U.S. and 68.06

percent for India. In future work, it would be desirable to consider ad valorem equivalents of services barriers of the type estimated by Jafari and Tarr (2014).

\section{Section III. The Theory of Preferential Trade Liberalization}

In this section, we outline the basic framework used to evaluate the effects of reciprocal liberalization between the United States and India (Fukase and Martin 2001). On the import side, the concepts of trade creation and trade diversion are central to the evaluation of discriminatory trade liberalization. Trade creation measures the gains from expanding trade in the products being liberalized. Trade diversion, by contrast, reflects the reductions in trade of products disadvantaged by preferential liberalization, and particularly the losses of government revenue associated with this phenomenon. 
Figure 4a Welfare impacts of US liberalization of imports from India

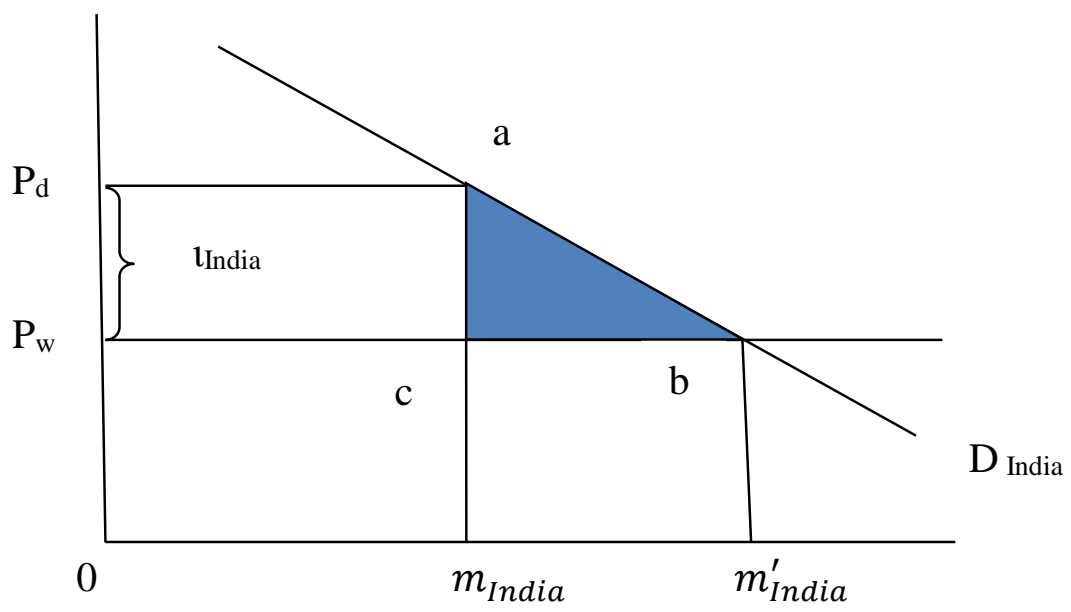

Figure 4b Welfare Impact of preferential liberalization on imports from non-partner countries

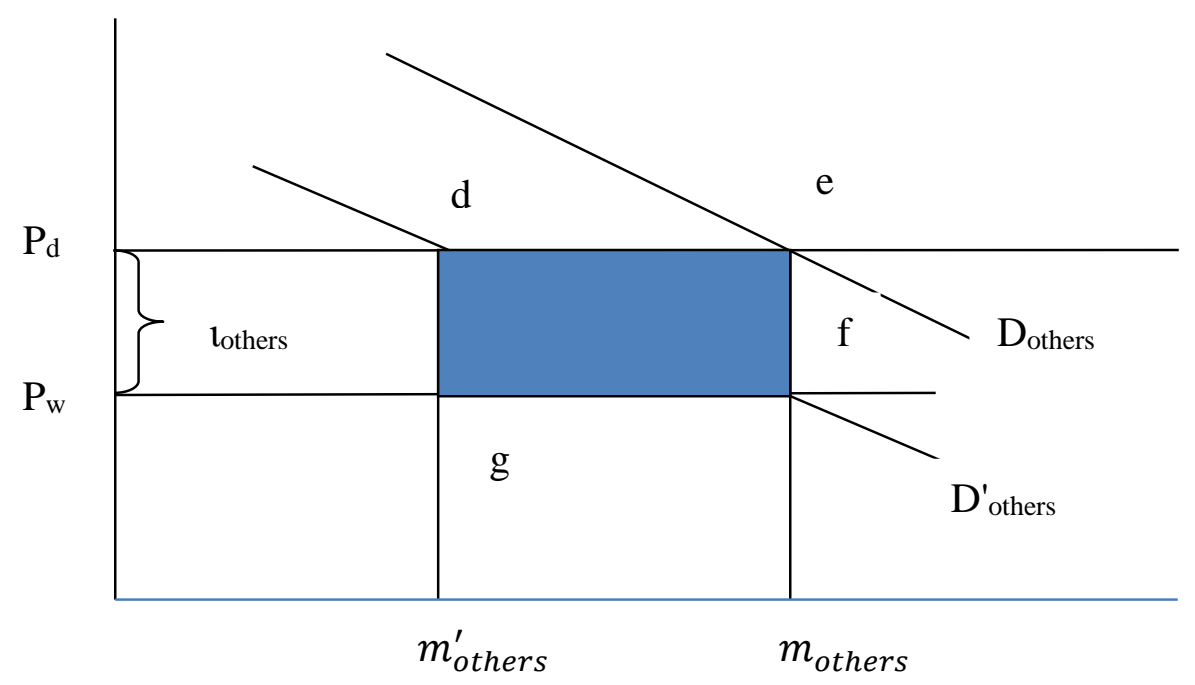

To measure these impacts, we first consider the effects of changes in the tariffs that the United States levies on its imports from India (or vice versa). To aid understanding of the concept of trade creation, the market for goods imported by the United States from India is illustrated in figure $4 \mathrm{a}$. In the initial equilibrium, the US imposes a tariff $\tau_{\text {India }}\left(\mathrm{P}_{\mathrm{d}}=\mathrm{P}_{\mathrm{w}}+\tau_{\text {India }}\right.$ where $\mathrm{P}_{\mathrm{d}}$ and $\mathrm{P}_{\mathrm{w}}$ are the domestic and the world price respectively). Let us now eliminate the tariff on imports from India. This reduces tariff revenues on initial imports from India by 
$P_{d} a c P_{w}$. However, the gains to consumers are greater as they increase the quantity of Indian goods that they purchase. Following the decline in the domestic price, consumers move down the (compensated) demand curve for Indian goods, DIndia from initial quantity $\mathrm{m}$ to final quantity m'. Consumers gain the value $P_{d} a c P_{w}$ that would formerly have been paid to the government in tariffs. In addition, consumer surplus increases by the area $a b c$. The net gain to the U.S. in this market can be approximated by the shaded area $a b c$. This is the welfare benefit from trade creation.

If the import distortion being liberalized is the only distortion in the economy, then the welfare impacts of liberalization can be analyzed by considering only the trade creation effects depicted above. If, however, there are distortions in other markets, the problem is one of the second best and the impacts of liberalization on trade flows through these barriers must be considered. Perhaps the best known type of second-best welfare effect when considering a preferential trade agreement is trade diversion. In the analytical framework used in this study, this potential source of loss is readily seen by examining conditions in the market for imports from non-partner countries, represented in figure $4 \mathrm{~b}$. Assuming that imports from non-partner countries are substitutes for imports from partner countries, the reduction in the price of imports from India shown in figure $4 \mathrm{~b}$ leads to a reduction in the demand for goods from non-partner countries, shifting the demand curve for these goods from $\mathrm{D}_{\text {others }}$ to $\mathrm{D}_{\text {others. }}$. This has adverse welfare consequences that can be measured by the tariff revenues collected on non-partner imports. The welfare loss to the US is also the resulting loss in tariff revenues, shown by the area defg.

Whether there is a net gain or loss to the importing country depends on the relative sizes of the two shaded areas. Clearly, the gains from trade creation will be larger, the higher the rate 
of protection initially applied on these trade flows, the more price responsive is the total domestic demand for these goods (particularly, the more substitutable are domestic and imported goods) and, if the size of the increase in trade is proportional to the initial trade volume, the larger the initial trade volume. Trade diversion costs are likely to be greater the higher the tariffs applied in the non-partner markets and the greater the reduction in the quantity of imports from these markets - a quantity that reflects both the size of the drop in domestic prices of goods from the partner, and the cross-price effect of the decline in the price of imports from the partner.

Terms of Trade (TOT) effects, which are defined as a change in export prices relative to import prices, are another key component of welfare changes, as an improvement in the terms of trade contributes to welfare gains. In the case of reciprocal liberalization, the TOT gains resulting from the improved access to the partner's market are likely to be central in evaluating the welfare consequence on the export side. In figure 4c, it is shown that the reduction in Indian tariffs on exports from the US shifts India's import demand curve for exports from ED to ED'. This causes the price received by US exporters to rise from $\mathrm{P}$ to $\mathrm{P}^{\prime}$. The result is an increase in the price received for these exports and an increase in the volume of exports from the U.S. to India (shaded area hijk).

For large traders such as the US and India, there are other potentially important terms-oftrade effects. ${ }^{6}$ An increase in a country's import demand associated with liberalization may lead to a rise in its import prices, causing the country's TOT to deteriorate. Liberalization also causes a reduction in input costs and hence improved competitiveness and exports. If this increase in export supplies causes a decline in export prices in both partner and non-partner markets, there may be a terms of trade effect that needs to be incorporated into the analysis.

\footnotetext{
${ }^{6}$ The GTAP model assumes that products are differentiated by origin (the Armington assumption).
} 


\section{Figure 4c Terms of Trade impacts of improved access to a partner}

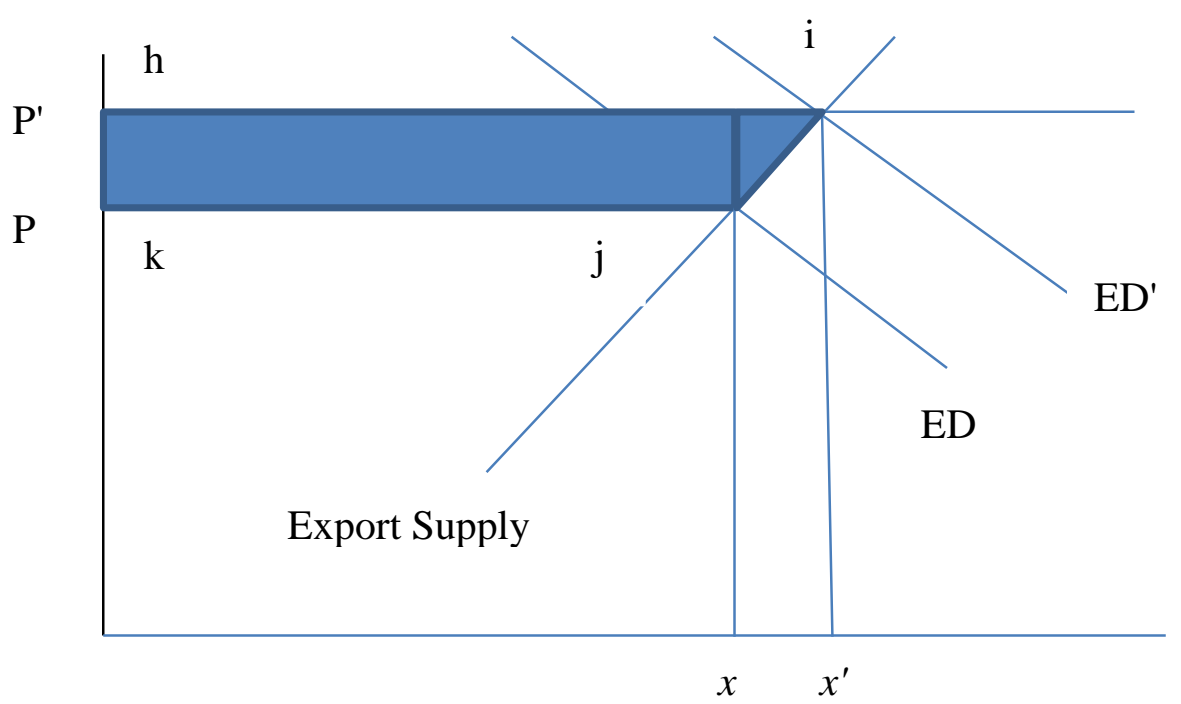

The net effect on the overall TOT depends primarily on the difference between the TOT loss resulting from trade expansion and the TOT gains from preferential access to the partner's market. All of the impacts of discriminatory trade liberalization outlined above need to be taken into account simultaneously in forming an overall assessment of the proposed approach. While diagrams of the type shown above aid understanding, they do not provide a practical basis for making an overall evaluation since many of the relationships depicted are interdependent. By contrast, quantitative models such as GTAP allow all of these effects to be taken into account at once.

\section{Section IV. Simulation Results}

\section{IV.1 US-India FTA}

\section{Trade and Output Effects}

In this section, we implement a series of simulations pertaining to a potential India-US FTA. We have aggregated the original 57 GTAP sectors and 113 countries/regions into 13 broad categories (see footnote 3) and 15 regions, namely, the United States, India, Australia/New Zealand, 
Canada/Mexico, EU27, Chile/Peru, Rest of LAC, Japan, China, ASEAN (TPP members), ASEAN (non TPP members), MENA, SAFTA, SSA and Others. Since the nature of goods and services liberalizations may be different, we first simulate the impacts of goods and services liberalization separately. Table 4a estimates the percentage changes to be expected in U.S-India bilateral trade and in total imports and exports when the United States and India reduce AVE protection for goods to zero on imports from each other. According to our simulation, U.S. exports to India increase by 63 percent while Indian exports to the U.S. rise by 15 percent. The expansion of U.S. exports to India tends to be large across all the goods sectors, ranging from 719 percent in processed agriculture to 23 percent in transport sector, reflecting generally high levels of initial protection in India. Given the relatively low initial US protection, Indian export growth to the U.S. tends to be much smaller overall. However India experiences a large export expansion in textiles and apparel, about 85 percent, followed by other light manufacturing (31 percent). As these sectors are labor-intensive, the employment effects resulting from the expansion of exports are disproportionately large. When the U.S. lowered its tariffs against Vietnam's goods from general to Most-favored Nation (MFN) rates in 2001 (Fukase and Martin 2001), Vietnam's exports of labor-intensive manufacturing such as clothing to the U.S. expanded dramatically, and this led to a disproportionately large job creation effect in Vietnam (Fukase 2013).

Table $4 \mathrm{~b}$ estimates the trade effects to be expected when the United States and India reduce their AVE protection for services by 50 percent. U.S. exports of services to India and those from India to the U.S. are expected to increase by 113 percent and 12 percent, respectively, which would lead to a rise in overall exports from the U.S. to India by 28 percent and from India to the U.S. by 5 percent. Interestingly, the liberalization of services would appear to impact the 
pattern of trade in goods differently in the U.S. and in India. In the United States, the liberalization of services appears to lead to a slight contraction in goods exports, with resources reallocated toward now more profitable service sectors. In contrast, the rise in exports of services from the United States to India appears to contribute to a rise in India's exports of "goods". This is perhaps because imported services provide important inputs into the production of goods, and the increased availability of efficient services may also reduce transaction/transportation costs. Several papers find that service imports may cause developing countries to increase their international competitiveness and facilitate exports (e.g., Cebula et al. 2011; Hoekman and Braga 1997). Analyzing U.S. trade data, Cebula et al. (2011) find that service imports from the U.S. have a significant and positive impact on goods exports to the U.S. in the case of low-income countries but not in the case of high-income countries. 
Table 4a Trade effects resulting from 100 percent AVE protection cut for goods

\begin{tabular}{|c|c|c|c|c|c|c|}
\hline & $\begin{array}{c}\text { Exports } \\
\text { from the } \\
\text { U.S. to India }\end{array}$ & $\begin{array}{l}\text { Exports } \\
\text { from India } \\
\text { to the U.S. }\end{array}$ & $\begin{array}{c}\text { Total } \\
\text { U.S. } \\
\text { imports }\end{array}$ & $\begin{array}{c}\text { Total } \\
\text { Indian } \\
\text { Imports }\end{array}$ & $\begin{array}{c}\text { Total } \\
\text { U.S. } \\
\text { Exports }\end{array}$ & $\begin{array}{l}\text { Total } \\
\text { Indian } \\
\text { exports }\end{array}$ \\
\hline Agriculture (\%) & 183.2 & 5.3 & 0.5 & 10.1 & 0.9 & 0.2 \\
\hline Processed agriculture (\%) & 718.8 & 11.6 & 0.4 & 11.0 & 1.4 & 0.7 \\
\hline Coal, oil, gas and other mining (\%) & 325.9 & 0.5 & 0.2 & -0.3 & 1.5 & 0.2 \\
\hline Textiles and apparel (\%) & 179.2 & 84.7 & 2.1 & 4.9 & 0.6 & 21.0 \\
\hline Other light manufacturing (\%) & 164.1 & 31.3 & 0.4 & 2.9 & -0.1 & 3.6 \\
\hline Paper and mineral products (\%) & 97.5 & 9.5 & 0.4 & 6.0 & 0.9 & 1.9 \\
\hline Chemical, rubber and plastic products (\%) & 83.0 & 6.2 & 0.4 & 4.3 & 0.7 & 1.5 \\
\hline Iron, steel and metal products (\%) & 187.6 & 1.8 & 0.5 & 2.5 & 2.8 & 0.4 \\
\hline Petroleum and coke products (\%) & 75.8 & 3.1 & 0.1 & 1.4 & 0.5 & 0.2 \\
\hline Transport equipment (\%) & 22.5 & 1.0 & 0.3 & 4.8 & 0.3 & 0.5 \\
\hline Electronics and machinery (\%) & 100.8 & 2.8 & 0.4 & 3.1 & 0.4 & 1.4 \\
\hline Other manufacturing (\%) & 143.9 & 0.7 & 0.3 & 11.8 & 4.8 & 0.4 \\
\hline Services (\%) & -0.1 & -0.2 & 0.3 & 0.3 & -0.5 & -0.4 \\
\hline Total (\%) & 62.5 & 14.7 & 0.4 & 2.3 & 0.5 & 2.6 \\
\hline Change in Trade Value (\$ million) & 15220 & 5502 & 8924 & 6563 & 6945 & 5584 \\
\hline
\end{tabular}

Table 4b Trade effects resulting from 50 percent AVE protection cut for services

\begin{tabular}{|c|c|c|c|c|c|c|}
\hline & $\begin{array}{c}\text { Exports } \\
\text { from the } \\
\text { U.S. to India }\end{array}$ & $\begin{array}{l}\text { Exports } \\
\text { from India } \\
\text { to the U.S. }\end{array}$ & $\begin{array}{c}\text { Total } \\
\text { U.S. } \\
\text { imports }\end{array}$ & $\begin{array}{c}\text { Total } \\
\text { Indian } \\
\text { Imports }\end{array}$ & $\begin{array}{c}\text { Total } \\
\text { U.S. } \\
\text { Exports }\end{array}$ & $\begin{array}{l}\text { Total } \\
\text { Indian } \\
\text { exports }\end{array}$ \\
\hline Agriculture (\%) & -0.2 & 0.0 & 0.0 & 0.0 & -0.1 & 0.1 \\
\hline Processed agriculture (\%) & -0.6 & 0.5 & 0.1 & -0.3 & -0.2 & 0.6 \\
\hline Coal, oil, gas and other mining (\%) & -0.2 & 0.0 & 0.0 & 0.0 & -0.2 & 0.1 \\
\hline Textiles and apparel (\%) & -1.2 & 1.5 & 0.1 & -0.7 & -0.5 & 1.4 \\
\hline Other light manufacturing (\%) & -0.8 & 1.1 & 0.1 & -0.4 & -0.4 & 1.0 \\
\hline Paper and mineral products (\%) & -0.8 & 0.8 & 0.1 & -0.5 & -0.3 & 0.7 \\
\hline Chemical, rubber and plastic products (\%) & -0.5 & 0.8 & 0.1 & -0.1 & -0.3 & 0.8 \\
\hline Iron, steel and metal products (\%) & -0.5 & 0.9 & 0.0 & 0.0 & -0.4 & 1.0 \\
\hline Petroleum and coke products (\%) & -0.1 & 0.0 & 0.0 & -0.1 & -0.1 & 0.1 \\
\hline Transport equipment (\%) & -0.7 & 1.3 & 0.1 & -0.5 & -0.3 & 1.2 \\
\hline Electronics and machinery (\%) & -1.1 & 2.0 & 0.1 & -0.6 & -0.4 & 1.9 \\
\hline Other manufacturing (\%) & -1.0 & 1.4 & 0.1 & -0.5 & -0.5 & 1.3 \\
\hline Services (\%) & 112.9 & 12.2 & 0.4 & 12.2 & 1.8 & 3.1 \\
\hline Total (\%) & 27.4 & 5.4 & 0.1 & 1.2 & 0.1 & 1.5 \\
\hline Change in Trade Value (\$ million) & 6670 & 2025 & 2643 & 3445 & 1680 & 3196 \\
\hline
\end{tabular}

Source: Authors' simulation Results. 
Table 4c Trade effects resulting from 100 percent AVE protection cut for goods and 50 percent cut for services

Agriculture (\%)

Processed agriculture (\%)

Coal, oil, gas and other mining (\%)

Textiles and apparel (\%)

Other light manufacturing (\%)

Paper and mineral products (\%)

Chemical, rubber and plastic products (\%)

Exports

Exports

Total

Total

Total

Total

from the from India

U.S. to India to the U.S.

U.S. Indian

U.S. Indian

Iron, steel and metal products (\%)

Petroleum and coke products (\%)

Transport equipment (\%)

Electronics and machinery (\%)

Other manufacturing (\%)

Services (\%)

Total (\%)

183.0
714.7

5.3

imports

Imports

Export exports

Change in Trade Value ( $\$$ million)

325.5

162.2

96.1

82.4

186.3

75.7

21.7

98.8

141.9

112.9

89.6

21829

2.3
0.7
7.4

0.5

$\begin{array}{ll}0.6 & 10.7 \\ 0.2 & -0.2\end{array}$

0.2

2.3

0.6

0.6

10.4

7.1

2.7

3.2

2.3

4.8

2.1

12.0

7606

7606
0.2

0.2

4.3

2.6

5.6

4.2

2.5

1.4

4.4

2.6

11.3

12.6

12.6
10180

10180

$0.8 \quad 0.2$

$1.1 \quad 1.1$

$1.4 \quad 0.3$

$0.1 \quad 22.7$

$\begin{array}{cc}0.1 & 22.7 \\ -0.5 & 4.6\end{array}$

$0.6 \quad 2.6$

$0.4 \quad 2.3$

$2.4 \quad 1.3$

$0.5 \quad 0.3$

$0.0 \quad 1.7$

$-0.1 \quad 3.2$

$4.2 \quad 1.6$

$1.6 \quad 3.1$

$\begin{array}{cc}0.7 & 4.1 \\ 9258 & 8925\end{array}$

Table 4d Trade effects resulting from 100 percent cut for goods and 50 percent cut for services plus India's MFN liberalization

\begin{tabular}{|c|c|c|c|c|c|c|}
\hline & $\begin{array}{c}\text { Exports } \\
\text { from the } \\
\text { U.S. to India }\end{array}$ & $\begin{array}{l}\text { Exports } \\
\text { from India } \\
\text { to the U.S. }\end{array}$ & $\begin{array}{c}\text { Total } \\
\text { U.S. } \\
\text { imports }\end{array}$ & $\begin{array}{c}\text { Total } \\
\text { Indian } \\
\text { Imports }\end{array}$ & $\begin{array}{c}\text { Total } \\
\text { U.S. } \\
\text { Exports }\end{array}$ & $\begin{array}{r}\text { Total } \\
\text { Indian } \\
\text { exports }\end{array}$ \\
\hline Agriculture (\%) & 13.7 & 31.3 & -0.1 & 80.0 & 0.7 & 24.3 \\
\hline Processed agriculture (\%) & 36.9 & 37.6 & -0.1 & 233.2 & 0.5 & 23.8 \\
\hline Coal, oil, gas and other mining (\%) & 41.3 & 43.3 & -0.3 & 12.1 & 0.2 & 48.5 \\
\hline Textiles and apparel (\%) & 43.6 & 134.4 & 2.3 & 50.0 & -0.3 & 55.0 \\
\hline Other light manufacturing (\%) & 44.1 & 67.2 & -0.2 & 32.2 & 0.5 & 33.1 \\
\hline Paper and mineral products (\%) & 25.8 & 27.6 & 0.0 & 26.0 & 0.5 & 19.2 \\
\hline Chemical, rubber and plastic products (\%) & 2.3 & 44.0 & 0.0 & 21.9 & 0.0 & 37.1 \\
\hline Iron, steel and metal products (\%) & 35.5 & 33.2 & 0.0 & 28.6 & 0.7 & 32.4 \\
\hline Petroleum and coke products (\%) & 14.4 & 32.6 & 0.0 & 9.6 & -0.8 & 26.4 \\
\hline Transport equipment (\%) & -21.4 & 25.4 & -0.2 & 14.1 & -0.5 & 25.0 \\
\hline Electronics and machinery (\%) & 12.0 & 48.3 & -0.2 & 15.1 & 0.5 & 46.9 \\
\hline Other manufacturing (\%) & 41.3 & 29.2 & 0.2 & 40.3 & 0.9 & 28.0 \\
\hline Services (\%) & 45.7 & 19.7 & 0.2 & 45.3 & 0.8 & 10.5 \\
\hline Total (\%) & 12.5 & 44.9 & 0.0 & 25.8 & 0.3 & 29.1 \\
\hline Change in Trade Value (\$ million) & 3043 & 16834 & 700 & 74752 & 3880 & 62837 \\
\hline
\end{tabular}

Source: Authors' simulation results. 
Table 5 Output effects (percent change in output)

Agriculture (\%)

Processed agriculture (\%)

Coal, oil, gas and other mining (\%)

Textiles and apparel (\%)

Other light manufacturing (\%)

Paper and mineral products (\%)

Chemical, rubber and plastic products (\%)

Iron, steel and metal products (\%)

Petroleum and coke products (\%)

Transport equipment (\%)

Electronics and machinery (\%)

Other manufacturing (\%)

Services (\%)

Source: Authors' simulation results.
Goods

Liberalization

US India

$0.10 \quad-0.06$

$0.05 \quad-0.31$

$-0.05 \quad-0.16$

$-0.92 \quad 7.05$

$-0.13$

0.02

0.05

0.29

0.09

0.00

$-0.07$

0.81

0.00
Services

Liberalization

US

$-0.05$

$-0.02$

$-0.04$

$-0.18$

$-0.07$

$-0.06$

$-0.18$

$-0.21$

0.01

$-0.14$

$-0.24$

$-0.23$

0.03
Goods + Services

Liberalization

US India

$0.05 \quad-0.01$

$0.04 \quad-0.24$

$-0.09 \quad-0.04$

$-1.10 \quad 7.83$

$-0.20 \quad 1.20$

$-0.04 \quad-0.42$

$-0.12 \quad-0.07$

$0.08 \quad-0.65$

$0.09-0.13$

$-0.13 \quad-1.09$

$-0.3-0.3$

$0.58 \quad-0.25$

$0.03-0.11$

\begin{tabular}{cr}
\multicolumn{3}{c}{$\begin{array}{c}\text { Goods + Services + } \\
\text { India MFN }\end{array}$} \\
\hline$\underline{\text { US }}$ & $\underline{\text { India }}$ \\
0.15 & -1.99 \\
0.03 & -8.89 \\
-0.03 & -1.91 \\
-1.28 & 19.07 \\
0.03 & 7.89 \\
0.04 & -1.12 \\
-0.05 & 4.31 \\
0.08 & -1.54 \\
-0.13 & 6.51 \\
-0.14 & -0.44 \\
0.12 & 2.13 \\
-0.16 & 8.71 \\
0.00 & 0.06 \\
\hline
\end{tabular}


Combining goods and service liberalizations, the results in table $4 \mathrm{c}$ predict that exports from the U.S. to India and those from India to the U.S. may expand by 90 percent and 20 percent respectively. The impacts on total trade for the United States are 0.6 percent and 0.7 percent increases in import and export values respectively whereas the corresponding figures are 3.5 percent and 4.1 percent for India. In terms of trade values, the resulting increase in bilateral trade (imports plus exports) is estimated to be $\$ 29$ billion (0.21 percent and 2.4 percent of the U.S.'s and India's initial GDP respectively). ${ }^{7}$ Overall, the U.S.'s total trade and that of India may increase by $\$ 22$ billion ( 0.16 percent of initial GDP) and by $\$ 19$ billion (1.6 percent of initial GDP) respectively.

Table $4 \mathrm{~d}$ presents the results of a scenario in which India first signs a free trade agreement with the United States and then liberalizes with all its other trading partners on an MFN basis. Using an India-US FTA for further liberalization may be particularly suitable for India relative to using mechanisms under the World Trade Organization (WTO). This is because India is not required to lower its tariff rates under the WTO as India's bound tariff rates are far higher than its applied rates; and an India-US FTA is likely to become a comprehensive, deep and symmetrical agreement while India has little obligation to reduce its protection at the WTO because of the special and differential treatment principle (Lawrence and Chadha 2004). The simulation results show that total Indian imports and exports both expand substantially by 26 percent and 29 percent respectively; and India's exports to the United States increase disproportionately relative to other countries (45 percent) since India continues to receive preferential market access in the US market. The rise in India's imports is especially large in the

\footnotetext{
${ }^{7}$ These estimates are based on the initial trade values in 2007, which is the reference year of GTAP 8 . As trade between the U.S. and India has continued to grow since 2007, the magnitude of the trade effect is likely to be larger if an FTA takes effect at a later time.
} 
processed agricultural sector (233 percent) whereas India's exports tend to expand across sectors, because of the real exchange rate depreciation associated with reduction in trade barriers (Salter 1959). In value terms, India's trade expansion is about seven times larger relative to the base scenario, with India's total trade expanding by $\$ 138$ billion (11 percent of initial GDP).

Table 5 reports the output effects resulting from the simulation experiments reported in tables $4 \mathrm{a}$ through $4 \mathrm{~d}$. Columns 1-2 of table 5 reveal that the impacts of goods liberalization on output are most pronounced in textiles and apparel: while the output of this sector in India increases by 7 percent, that in the U.S. contracts by 0.9 percent. It appears that, resulting from goods liberalization, productive resources are allocated more efficiently and India is able to allocate additional resources to sectors in which it has a comparative advantage.

As a result of service trade liberalization (columns 3-4), the output of services contracts slightly in India due to increased competition from the United States. However, the increased efficiency of the services sectors contributes to an expansion of output across all goods sectors. This result is broadly consistent with the view that opening services sectors to foreign providers is a channel through which services liberalization contributes to improved performance of downstream manufacturing sectors (e.g., Arnold et al. 2012 for India; Arnold, Javorcik and Mattoo 2011 for Czech Republic). For instance, examining the link between policy reforms in services and the production of manufacturing firms from 1993 to 2005, Arnold et al. (2012) show that India's reforms in services, which include banking, telecommunications, insurance and transport reforms, had positive effects on the productivity of manufacturing.

Combining goods and services liberalizations (columns 5-6), the performance of the Indian goods sector tends to be slightly better relative to goods market liberalization alone. For instance, the change in textile and apparel output increases from 7.1 percent to 7.8 percent. When 
India extends its goods and services liberalization to all its suppliers (last two columns of table 5), this strategy appears to accelerate resource reallocation across sectors in India. Relative to the baseline scenario, the expansion of the textiles and apparel sector more than doubles; other sectors such as light manufacturing, chemical, rubber and plastic products, petroleum and coke products also expand sizably; but the contractions of some sectors, for instance, that of processed agriculture, are more pronounced. An India-US FTA is also likely to promote resource reallocation in the United States, but its impact on the structure of U.S. production appears to be generally small.

\section{Welfare Effects}

In order to analyze the impacts of FTAs on economic welfare, we use a decomposition of the Equivalent Variation (EV) into allocative efficiency and terms of trade (TOT) components, following Huff and Hertel (2000). The allocative efficiency effects are further decomposed into trade creation, trade diversion effects and other allocative efficiency components. ${ }^{8}$ The first eight columns of table 6 report the results of welfare decomposition using the same scenarios described above (the baseline scenario is reported in bold). The economic impacts from goods liberalization are positive for both the United States and India as they experience welfare gains of $\$ 2.3$ billion and $\$ 0.2$ billion respectively (column 1-2). The gains coming from the TOT component are especially large for the United States (\$2.0 billion), mainly reflecting initially high protection in India. India appears to suffer from some trade diversion in goods

\footnotetext{
${ }^{8}$ The GTAP model incorporates many pre-existing distortions in the forms of taxes and subsidies (Huff and Hertel 2000). The welfare changes in the model are attributed to the interactions between taxes (or subsidies) and equilibrium quantity changes taking place over the course of simulations. Among allocative efficiency effects, this paper focuses on quantifying trade creation and trade diversion type effects illustrated in figure 4ab. These effects are measured as the summation of the tariff revenue weighted by imports quantity changes, i.e., by aggregating the changes in tariff revenues within FTA (trade creation) and outside of the FTA (trade diversion) (Hertel et al. 2007). The welfare effect resulting from changes in the relative prices of savings and investment is not included in our welfare decomposition.
} 
liberalization ${ }^{9}$ although generally improved allocative efficiency may outweigh this loss. The corresponding figures resulting from services liberalization for the U.S. and India are \$1.4 billion and \$1.2 billion (Columns 3-4).

When goods and services liberalizations are combined (baseline scenario), the United States and India gain by $\$ 3.7$ billion and $\$ 1.4$ billion respectively (about 0.03 percent and 0.1 percent of initial U.S. and Indian GDP respectively) (Columns 5-6). When India extends the removal of barriers on an MFN basis (Columns 7-8), India's welfare expands dramatically to $\$ 13.5$ billion (about 1.0 percent of its initial GDP) as its much larger allocative efficiency gains far surpass its deteriorating TOT effects. The strategy of lowering external barriers in the aftermath of an FTA is documented both in ASEAN (Calvo-Pardo, Freund, and Ornelas 2011) and in Latin America (Estevadeordal, Freund and Ornelas 2008). For instance, Estevadeordal et al. (2008) find strong evidence that regional agreements induced a faster decline in external tariffs in Latin America and conclude that free trade areas are likely to be building blocks in the region.

Experiments in the last four columns of table 6 separate the baseline scenario into two parts, i.e., the effects from the US lowering its protection against India's exports (Column 9-10) and from India's doing so against U.S. exports (Columns 11-12). The results reveal that both countries lose if they only lower their own barriers without obtaining reciprocal commitments, as gains resulting from doing so appear to be reaped by their partners. Our finding suggests that FTA models which focus only on the import side are misleading, and highlights the importance of negotiating concessions by FTA partner countries.

\footnotetext{
${ }^{9}$ This result is partly attributable to the fact that India's initial AVE protection of 9.9 percent against the U.S. goods (table $3 b$ ) is lower than the rates India applies to its other trading partners. Thus, as a result of the discriminatory trade liberalization, India would expect a large tariff revenue loss from the other partners.
} 
Table 6 Welfare effects of potential FTA between India and the United States (\$ million)

\begin{tabular}{|c|c|c|c|c|c|c|c|c|c|c|c|c|}
\hline & \multicolumn{2}{|c|}{$\begin{array}{c}\text { Goods } \\
\text { Liberalization }\end{array}$} & \multicolumn{2}{|c|}{$\begin{array}{c}\text { Services } \\
\text { Liberalization }\end{array}$} & \multicolumn{2}{|c|}{$\begin{array}{c}\text { Goods + Services } \\
\text { Liberalization }\end{array}$} & \multicolumn{2}{|c|}{$\begin{array}{c}\text { Goods + Services } \\
\text { + India MFN }\end{array}$} & \multicolumn{2}{|c|}{$\begin{array}{l}\text { Only the U.S. } \\
\text { removes } \\
\text { protection }\end{array}$} & \multicolumn{2}{|c|}{$\begin{array}{l}\text { Only India } \\
\text { removes } \\
\text { protection }\end{array}$} \\
\hline & $\underline{\text { US }}$ & India & $\underline{\text { US }}$ & India & $\underline{\text { US }}$ & India & $\underline{\text { US }}$ & India & $\underline{\text { US }}$ & India & $\underline{\text { US }}$ & India \\
\hline 1. Allocative efficiency effect & 289 & 234 & 257 & 1550 & 536 & 1804 & -171 & 26205 & -74 & 738 & 642 & 1097 \\
\hline 1.1 Net TC vs. TD & 80 & -462 & 176 & 1340 & 176 & 898 & -221 & 16361 & -71 & & & 310 \\
\hline Trade Creation (TC) & 207 & 939 & 292 & 3292 & 292 & 4241 & 482 & & 247 & & & 4144 \\
\hline Trade Diversion (TD) & -127 & -1401 & -116 & -1952 & -116 & -3343 & -704 & & -319 & & & -3834 \\
\hline 1.2 Other allocative efficiency effect & 210 & 696 & 80 & 210 & 360 & 906 & 50 & 9844 & -2 & 738 & 642 & 786 \\
\hline 2. Terms of Trade (TOT) Effects & 2033 & 9 & 1104 & -400 & 3133 & -392 & 642 & -12692 & -477 & 1227 & 3551 & -1647 \\
\hline Total EV Change & 2322 & 243 & 1360 & 1150 & 3669 & 1412 & 471 & 13513 & -551 & 1965 & 4193 & -550 \\
\hline
\end{tabular}

Source: authors' simulation results. 
Table 7a Total and incremental welfare effects under different scenarios A1W-C5W (\$ million)

\section{A. Alternative FTA}

1. Allocative efficiency effect

1.1 Net TC vs. TD

Trade Creation (TC)

Trade Diversion (TD)

1.2 Other allocative efficiency effect

2.Terms of Trade (TOT) Effects

Total EV Change (A)

B. Alternative FTA (A) + India-US

1. Allocative efficiency effect

1.1 Net TC vs. TD

Trade Creation (TC)

Trade Diversion (TD)

1.2 Other allocative efficiency effect

2. Terms of Trade (TOT) Effects

\section{Total EV Change (B)}

C. Alternative FTA (A) + India-US (B) + India MFN Liberalization

1. Allocative efficiency effect

1.1 Net TC vs. TD Trade Creation (TC) Trade Diversion (TD)

1.2 Other allocative efficiency effect

2. Terms of Trade (TOT) Effects Total EV Change (C)

D. Incremental EV Change (B) - (A)

E. Incremental EV Change (C) - (B)

Source: Authors' simulation results.

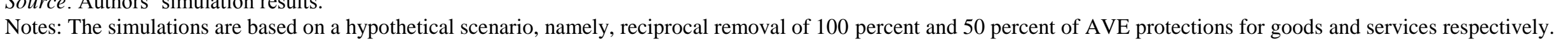

A1W: TPP

$\begin{array}{rrrrr}\underline{\text { US }} & \underline{\text { India }} & \underline{\text { US }} & \underline{\text { India }} \\ 918 & -108 & & 1184 & -165 \\ 334 & & 541 & \\ 709 & & 913 & \\ -375 & & & -371 & \end{array}$

\begin{tabular}{cr} 
A3W: India-EU27 \\
\hline$\underline{\text { US }}$ & $\underline{\text { India }}$ \\
-74 & 4410 \\
& 3677 \\
& 8640 \\
& -4963
\end{tabular}

$584 \quad 642$ $\frac{\text { A4W: India-ASEAN }}{\underline{\text { US }} \underline{\text { India }}}$

$-30 \quad 5651$

\section{6}

8293

$-4828$

$5169-222$

6352

\section{B1W: A1W}

+India-US

US India

$1480 \quad 1701$

$541 \quad 830$

$973 \quad 4136$

$-433-3306$

$940 \quad 871$

$8549-649$

$10030 \quad 1052$

C1W: B1W

+ India MFN

US India

$819 \quad 26116$

$184 \quad 16285$

$1124 \quad 16285$

$-940$

$635 \quad 9831$

$6103-12949$

$6922 \quad 13167$

$3678 \quad 1371$

12115

12115

635

+ India-US

$\frac{+ \text { India-US }}{\underline{\text { US }} \underline{\text { India }}}$

$1713 \quad 1656$

$720 \quad 807$

$1197 \quad 4126$

$-477 \quad-3319$

$993 \quad 849$

$8242 \quad-646$

99541009

C2W: B2W

+ India MFN

US India

$1085 \quad \underline{\underline{\text { India }}}$

$391 \quad 16264$

$1302 \quad 16264$

$-911$

6949801

$5822-12946$

$6907 \quad 13119$

$3601 \quad 1396$

$-3047 \quad 12110$

$-3047 \quad 12110$

\begin{tabular}{rr} 
& 733 \\
-91 & -2284 \\
\hline
\end{tabular}

$-165 \quad 2126$

B3W: A3W

+ India-US

$\frac{\text { US }}{327} \quad \frac{\text { India }}{6945}$

$54 \quad 3677$

$311 \quad 11590$

$-257 \quad-7913$

$274 \quad 3268$

$2445-2250$

27724696

C3W: B3W

+ India MFN

3212

C4W: B4W

+ India MFN

2186
-3133

US India

US India

$\begin{array}{llll}-165 & \overline{\text { 27054 }} & \underline{\text { US }} & \end{array}$

$-191 \quad 17143$

$-207$

$420 \quad 17143$

457

16697

16697

$-611$

$\begin{array}{rrr}-611 & & -664 \\ 26 & 9911 & 40\end{array}$

$\begin{array}{llll}351 & -10480 & 511 & -11782\end{array}$

$186 \quad 16574$

$344 \quad 14947$

$\begin{array}{llll}2937 & 2569 & 3234 & 2212\end{array}$

$\begin{array}{llll}-2586 & 11878 & -2868 & 10217\end{array}$

B5W: AW5

+ India-US

C5W: B5W

+ India MFN

$-980$

A5W: TPP US-EU27

$\frac{\text { India-EU27 India-ASEAN }}{\underline{\text { US }} \underline{\text { India }}}$

209611130

$912 \quad 6715$

$1465 \quad 15173$

$-554 \quad-8458$

$185 \quad 4415$

$10458 \quad-4968$

$12555 \quad 6162$

US India

246513836

$1005 \quad 8685$

$1763 \quad 16301$

$-758 \quad-7616$

$1460 \quad 5151$

$12731 \quad-4861$

$15196 \quad 8975$

US India

$2078 \quad 27338$

$844 \quad 17291$

$1824 \quad 17291$

$1235 \quad 10047$

$10807 \quad-10109$

$12885 \quad 17229$

$2642 \quad 2813$

$-2311 \quad 8254$


Table 7b Total and incremental changes in trade (imports plus exports) under different scenarios A1T- C5T (\$ million)

\begin{tabular}{|c|c|c|c|c|c|c|c|c|c|c|}
\hline \multirow[t]{2}{*}{ A. Alternative FTA } & \multicolumn{2}{|c|}{ A1T: TPP } & \multicolumn{2}{|c|}{ A2T: US-EU27 } & \multicolumn{2}{|c|}{ A3T: India-EU27 } & \multicolumn{2}{|c|}{ A4T: India-ASEAN } & \multicolumn{2}{|c|}{$\begin{array}{c}\text { A5T : TPP US-EU27 } \\
\text { India-EU27 India-ASEAN }\end{array}$} \\
\hline & $\underline{\text { US }}$ & India & $\underline{\text { US }}$ & India & $\underline{\text { US }}$ & India & $\underline{\text { US }}$ & India & $\underline{\text { US }}$ & India \\
\hline 1. Change in Exports (\$ million) & 15087 & -316 & 27416 & -267 & -355 & 22213 & -572 & 17182 & 41085 & 35686 \\
\hline To Partners & 28973 & & 42171 & & & 15301 & & 6539 & 63443 & 24656 \\
\hline To Non-partners & -13886 & & -14755 & & & 6912 & & 10643 & -22358 & 11030 \\
\hline 2. Change in Imports (\$ million) & 21020 & -649 & 34753 & -737 & -2766 & 25631 & -748 & 20044 & 51926 & 40593 \\
\hline From Partners & 23312 & & 41260 & & & 65652 & & 43126 & 56017 & 89148 \\
\hline From Non-partners & -2292 & & -6507 & & & -40021 & & -23083 & -4091 & -48556 \\
\hline Total Trade Change $1+2$ (A) & 36107 & -965 & 62169 & -1004 & -3121 & 47844 & -1320 & 37226 & 93011 & 76279 \\
\hline Of which: Change in India-US Trade & -570 & -570 & -812 & -816 & -2893 & -3051 & 194 & 49 & -3967 & -4223 \\
\hline \multirow[t]{2}{*}{ B. Alternative FTA (A) + India-US } & \multicolumn{2}{|c|}{$\begin{array}{l}\text { B1T: A1T } \\
+ \text { +India-US }\end{array}$} & \multicolumn{2}{|c|}{$\begin{array}{l}\text { B2T: A2T } \\
+ \text { India-US }\end{array}$} & \multicolumn{2}{|c|}{$\begin{array}{c}\text { B3T: A3T } \\
+ \text { India-US }\end{array}$} & \multicolumn{2}{|c|}{$\begin{array}{c}\text { B4T: A4T } \\
+ \text { India-US }\end{array}$} & \multicolumn{2}{|c|}{$\begin{array}{l}\text { B5T: A5T } \\
+ \text { India-US } \\
\end{array}$} \\
\hline & $\underline{\text { US }}$ & $\underline{\text { India }}$ & $\underline{\text { US }}$ & $\underline{\text { India }}$ & $\underline{\text { US }}$ & $\underline{\text { India }}$ & $\underline{\text { US }}$ & $\underline{\text { India }}$ & $\underline{\text { US }}$ & $\underline{\text { India }}$ \\
\hline 1. Change in Exports (\$ million) & 24177 & 8451 & 36429 & 8424 & 7676 & 29325 & 8094 & 25148 & 48413 & 42179 \\
\hline To Partners & 47211 & 7219 & 58936 & 7067 & 14019 & 24000 & 18036 & 16271 & 68593 & 40992 \\
\hline To Non-partners & -23034 & 1232 & -22506 & 1357 & -6342 & 5325 & -9942 & 8877 & -20179 & 1187 \\
\hline 2. Change in Imports (\$ million) & 33429 & 9350 & 46908 & 9157 & 7966 & 33701 & 10752 & 29081 & 61686 & 47964 \\
\hline From Partners & 31521 & 21774 & 50092 & 21697 & 9310 & 74594 & 10140 & 59217 & 67215 & 93807 \\
\hline From Non-partners & 1909 & -12424 & -3184 & -12540 & -1344 & -40893 & 612 & -30134 & -5529 & -45843 \\
\hline Total Trade Change $1+2$ (B) & 57606 & 17801 & 83337 & 17581 & 15642 & 63026 & 18846 & 54229 & 110099 & 90143 \\
\hline Of which: Change in India-US Trade & 28662 & 28993 & 28444 & 28763 & 23329 & 23410 & 28176 & 28254 & 20241 & 20143 \\
\hline
\end{tabular}


(Table 7b Continued)

\begin{tabular}{|c|c|c|c|c|c|c|c|c|c|c|}
\hline \multirow[t]{2}{*}{$\begin{array}{l}\text { C. Alternative FTA (A) + India-US (B) + } \\
\text { India MFN Liberalization }\end{array}$} & \multicolumn{2}{|c|}{$\begin{aligned} & \text { C1T: B1T } \\
&+ \text { India MFN } \\
&\end{aligned}$} & \multicolumn{2}{|c|}{$\begin{aligned} & \text { C2T: B2T } \\
&+ \text { India MFN } \\
&\end{aligned}$} & \multicolumn{2}{|c|}{$\begin{aligned} & \text { C3T: B3T } \\
&+ \text { India MFN } \\
&\end{aligned}$} & \multicolumn{2}{|c|}{$\begin{aligned} & \text { C4T: B4T } \\
+ & \text { India MFN }\end{aligned}$} & \multicolumn{2}{|c|}{$\begin{aligned} & \text { C5T: B5T } \\
&+ \text { India MFN } \\
&\end{aligned}$} \\
\hline & $\underline{\text { US }}$ & $\underline{\text { India }}$ & $\underline{\text { US }}$ & $\underline{\text { India }}$ & $\underline{\text { US }}$ & $\underline{\text { India }}$ & $\underline{\text { US }}$ & $\underline{\text { India }}$ & $\underline{\text { US }}$ & $\underline{\text { India }}$ \\
\hline 1. Change in Exports ( $\$$ million) & 19428 & 62541 & 31753 & 62475 & 4015 & 66351 & 4313 & 64707 & 45674 & 67325 \\
\hline To Partners & 31829 & 16423 & 45313 & 16271 & 3545 & 38529 & 3269 & 25336 & 62575 & 44015 \\
\hline To Non-partners & -12401 & 46118 & -13560 & 46204 & 470 & 27822 & 1044 & 39371 & -16901 & 23310 \\
\hline 2. Change in Imports (\$ million) & 22610 & 74138 & 36230 & 73903 & 787 & 79168 & 1116 & 76966 & 55378 & 79702 \\
\hline From Partners & 37270 & & 54632 & & 15237 & & 16614 & & 70057 & \\
\hline From Non-partners & -14660 & & -18402 & & -14449 & & -15498 & & -14679 & \\
\hline Total Trade Change $1+2$ (C) & 42038 & 136679 & 67983 & 136378 & 4802 & 145519 & 5429 & 141673 & 101052 & 147027 \\
\hline Of which: Change in India-US Trade & 19776 & 19107 & 19585 & 18902 & 18781 & 18202 & 19883 & 19243 & 16143 & 15616 \\
\hline D. Incremental Trade Change (B) - (A) & 21499 & 18766 & 21168 & 18585 & 18763 & 15182 & 20166 & 17003 & 17088 & 13864 \\
\hline Of which: Change in India-US Trade ${ }^{a}$ & 29232 & 29563 & 29256 & 29579 & 26222 & 26461 & 27982 & 28205 & 24208 & 24366 \\
\hline E. Incremental Trade Change (C) - (B) & -15568 & 118788 & -15354 & 118798 & -10840 & 82493 & -13417 & 87444 & -9047 & 56884 \\
\hline Of which: Change in India-US Trade ${ }^{a}$ & -8886 & -9886 & -8859 & -9861 & -4548 & -5208 & -8293 & -9011 & -4098 & -4527 \\
\hline
\end{tabular}
Source: Authors'simulation results.

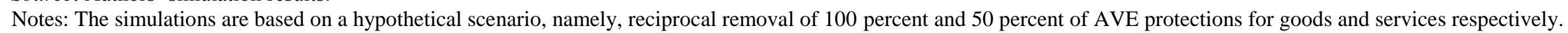

a The differences in bilateral trade between the United States and India reflect the differences between "cost, insurance and freight" (CIF) and "free on board" (FOB). 


\section{IV.2 India-US FTA in the Presence of Other FTAs}

The series of simulations in Section IV.1 assume that both countries negotiate only an India-US FTA. However, as the United States and India have already begun negotiating other FTAs, an important question arises of how the welfare and trade impacts of an India-US FTA are affected by prior decisions to proceed with other agreements. To answer this question, we first consider the impacts of several regional agreements that are under negotiation. Then, we will examine what would happen if the United States and/or India were to add an India-US FTA "after" the completion of any or all of the other agreements.

\section{Welfare Effects}

Panel A of table 7a considers the welfare consequences of alternative FTAs, namely under the $\mathrm{TPP}^{10}$ (scenario A1W) and the US-EU FTA (scenario A2W) for the United States as well as an India-EU FTA (scenario A3W) and an India-ASEAN FTA (scenario A4W). For the sake of transparency and for the purpose of comparing the results of alternative FTAs with an India-US FTA which does not yet exist, we apply the same assumption applied to the preceding simulations, i.e. 100 percent AVE tariff cuts for goods and 50 percent cuts for services each other.

The results suggest that the United States would gain roughly equally from the TPP and US-EU FTA ( $\$ 6.4$ billion) and that the welfare gains from each of these agreements appear to be larger than that resulting from a potential India-US FTA ( $\$ 3.7$ billion). Turning to alternative FTA partners for India, the welfare gains for India from an India-EU FTA and an India-ASEAN FTA are estimated to be $\$ 2.1$ billion and $\$ 2.5$ billion respectively. These gains are also larger

\footnotetext{
${ }^{10}$ At the time of writing (2013), eleven official TPP members included: Australia, Brunei Darussalam, Canada, Chile, Malaysia, Mexico, New Zealand, Peru, Singapore, the United States, and Vietnam.
} 
than the gains likely to result from a potential India-US FTA presented in table 6 ( $\$ 1.4$ billion). ${ }^{11}$

Scenarios A1W-A4W of Panel A in table 7a show that the countries that are excluded from FTAs tend to lose because they are discriminated against in FTA members' markets. These losses are particularly marked for India when the US concludes an FTA with Europe (loss of $\$ 387$ million/year) and India's exports to both these major markets face greater competition from suppliers within these trading blocs.

The last two columns show what happens if we combine all these FTAs, namely, the TPP, US-EU, India-EU and India-ASEAN (scenario A5W). The results show that both the United States and India gain much more than under any individual FTA ( $\$ 12.6$ billion for the United States and $\$ 6.2$ billion for India).

Panel B of table 7a reports the "total" welfare changes resulting from adding an India-US FTA involving both goods and services to each alternative FTA evaluated in Panel A (scenarios B1W-B5W). The results show that the total welfare would rise by adding an India-US FTA to prior agreements in each case. Panel D of table 7a shows the "incremental" benefits resulting from adding an India-US FTA, which are the differences between welfare gains reflected in Panels A and B. Comparing the welfare changes in Panel E with those in the baseline scenario (Columns 5-6 in table 6), the benefits to India are found to rise if it has undertaken prior agreements. With an India-EU agreement in place, for example, the gains from an India-US agreement rise from $\$ 1.4$ billion (baseline scenario) to $\$ 2.6$ billion for India (scenario B3W). Similarly, given an India-ASEAN agreement, the incremental gains from an India-US FTA rise

\footnotetext{
${ }^{11}$ However, the results need to be interpreted in the context of our assumptions. These are estimates of the potential and do not take into account leakages from measures such as "sensitive" products that might later be excluded from liberalization. For instance, in the ASEAN-India FTA, India has excluded a number of agricultural products from liberalization, putting them in the "Exclusion List" (Hoda and Gulati 2014).
} 
to $\$ 2.2$ billion (scenario $\mathrm{B} 4 \mathrm{~W}$ ). ${ }^{12}$ With all of the other agreements in place, the incremental gains from an India-US agreement rise to $\$ 2.8$ billion.

Panel C in table 7a reports the "total" welfare effects when India liberalizes on an MFN basis conditional on one or more prior agreements including an India-US FTA (scenarios C1WC5W). The results show that the benefits for India tend to rise substantially relative to the corresponding scenarios explored in this paper ( $\$ 17$ billion). ${ }^{13}$ For the United States, the incremental welfare change resulting from India's MFN liberalization is negative (Panel E), as it loses from the erosion of its preferential access to the Indian market.

\section{Trade Effects}

Table $7 \mathrm{~b}$ repeats the same experiments, but reports the trade effects (evaluated by the changes in import plus export values) instead of the welfare measures. Panel A shows that the United States and India would experience a rise in trade by concluding an FTA, while the excluded country tends to lose trade (scenarios A1T-A4T). For instance, following the conclusion of the TPP (scenario A1T) and an US-EU FTA (scenario A2T), the U.S. trade would increase by $\$ 36$ billion and by $\$ 62$ billion respectively. If the trade effects from the TPP and a US-EU FTA are combined (scenarios A1T $+\mathrm{A} 2 \mathrm{~T}$ ), the change in total trade for the United States would rise to $\$ 98$ billion. ${ }^{14}$ However, these agreements would lead Indian trade to decrease by about $\$ 1$ billion in scenarios A1T and A2T and by $\$ 2$ billion in the combined scenario of A1T and A2T. Panel A

\footnotetext{
${ }^{12}$ This is mainly because, with an India-ASEAN agreement in place, India would have reduced its initially high barriers against the ASEAN market (23.3 percent) (table 2b). Thus, the loss from trade diversion by adding an IndiaUS FTA would be smaller.

${ }^{13}$ It is noted that the "incremental" benefit from unilateral liberalization tends to be smaller relative to the corresponding scenario without prior agreements. For instance, under scenario $\mathrm{C} 5 \mathrm{~W}$, the incremental gain coming from unilateral liberalization of $\$ 8$ billion (Panel E) is smaller than the corresponding scenario without prior agreements of $\$ 12$ billion (the difference between column 6 and column 8 in table 6). The smaller net gain from unilateral liberalization conditional on more prior FTAs is not surprising, since the scope of the liberalization becomes smaller when India has already removed its protection against more FTA partners.

${ }^{14}$ The result of the combined scenario is not reported in table $7 \mathrm{~b}$ in order to conserve the space.
} 
of table $7 \mathrm{~b}$ also shows that the trade effect resulting from concluding an alternative FTA on Indian-US bilateral trade tends to be negative except in scenario A4T.

Panel B and Panel D in table 7b confirm that adding an India-US FTA conditional on prior FTA agreements creates trade for both countries (scenarios B1T-B5T). For instance, by concluding an India-US FTA in addition to the TPP (scenario B1T) or an US-EU FTA (scenario B2T), the total U.S. trade may increase by $\$ 58$ billion and by $\$ 83$ billion respectively. If TPP, a US-EU FTA and an India-US FTA are combined (scenarios B1T + B2T), the change in total trade for the United States would rise to $\$ 119$ billion (not reported in table $7 b$ ). For India, concluding an FTA with the United States may lead to an increase in its total trade by $\$ 18$ billion in scenarios B1T and B2T and by $\$ 17$ billion in the combined scenario of B1T and B2T. In terms of the impacts of these scenarios on trade between India and the United States, the estimated increase in bilateral trade ranges from $\$ 20$ billion in scenario B5T to $\$ 29$ billion in scenario B1T.

With India extending its concession on an MFN basis (Panel C), India's trade would expand considerably while the US's trade would decrease subsequent to the loss of the preference (scenarios C1T-C5T). As a result, the largest trade effects are found in the combination of scenario B1T and B2T for the United States ( $\$ 119$ billion) and in scenario C5T for India ( $\$ 147$ billion).

Finally, appendix table A shows how these free trade agreements (baseline scenario and scenarios A1T-C5T) would impact trade for non-member countries/regions. (The numbers of scenarios in appendix table A correspond to those in table 7b.) The results broadly confirm that countries tend to expand trade by concluding an FTA whereas the non-party countries lose from trade diversion. For instance, China appears to lose trade by not entering into any of these FTAs, although the magnitudes of loss vary from $\$ 680$ million (scenario C5T) to $\$ 11$ billion (scenario 
B5T). In scenarios C1T-C5T under which India extends unilateral liberalization after forging FTA(s), some countries appear to experience increases in trade resulting from improved access to the Indian market.

\section{Section V. Conclusion}

This paper explored the economic implications of a potential FTA between India and the United States using an applied general equilibrium model. Since the nature of the liberalization to be adopted is unknown at this stage, the potential impacts of an FTA are evaluated under a hypothetical scenario, namely 100 percent and 50 percent Ad Valorem Equivalent (AVE) tariff cuts for goods and services respectively. The results reveal that the overall impacts of an IndiaUS FTA could be positive both for the United States and India. While gains from trade creation tend to be offset by trade diversion on the import side, both countries appear to gain from improved access to each other's markets on the export side. The U.S. is likely to gain largely through terms of trade improvement for its goods and services as the initial protection in India is particularly high. India appears to experience an expansion of exports and of output especially in the textiles and apparel sectors. Moreover, the availability of more efficient "services" imported from the United States appears to have positive impacts on production and exports of "goods" in India.

As the United States and India are negotiating other FTAs such as the US-EU agreement, the Trans-Pacific Partnership (TPP), and India's agreement with the Association of Southeast Asian Nations (ASEAN), the paper explored how the economic implications of an India-US FTA vary depending on the existence of different prior FTAs. The results reveal that adding an IndiaUS FTA to prior agreements tends to bring additional welfare benefits to both countries. In 
particular, India would be likely to gain substantially if it were to conclude an FTA with the U.S. and other trading partners and then to extend its commitment to all its trading partners on an MFN basis. This is because MFN liberalization unwinds costly trade diversion and promotes a more efficient resource allocation towards sectors in which India has a comparative advantage. Finally, since countries excluded from FTAs tend to lose since they are discriminated against in FTA parties' markets and their trade is diverted in favor of FTA members, both the United States and India appear to have an incentive to enlarge the scopes of their FTAs. All the above findings suggest that an India-US FTA may potentially become a building block towards a more liberal trade regime for both countries.

Finally, our simulation exercises are subject to a number of limitations and many related issues may be subjects for future research. First, since the base year of our simulations is 2007 and our scenarios are based on simplified assumptions, future simulations might use actual liberalization schedules (when available) along with updated data. Second, it is well known that trade-weighted averages of tariff rates tend to underestimate the impact of protection and that this in turn is likely to result in the underestimate of welfare changes. In order to overcome this problem, more refined aggregators of trade distortions of a type done by Laborde et al. (2011) would be needed. Third, while our results suggest both countries gain in aggregate resulting from an FTA, we do not address the distributional consequences of trade liberalization. As there exist studies which suggest negative impacts of trade reforms on poverty in India (e.g., Anderson, Cockburn and Martin 2010; Topalova 2010) ${ }^{15}$ further studies would be required to evaluate the effects of an India-US FTA on the poor. Despite these limitations, it is hoped that our analytical

\footnotetext{
${ }^{15}$ Examining the 1991 Indian trade liberalization episode, Topalova (2010) finds that rural districts, in which production sectors more exposed to import liberalization were concentrated, experienced slower reduction in poverty in India.
} 
framework and simulation results may provide some ingredients for ongoing discussions concerning a potential India-US FTA.

\section{References}

Anderson, Kym, John Cockburn, and Will Martin, 2010. Agricultural Price Distortions, Inequality, and Poverty. Washington: World Bank.

Arnold, Jens, Beata Javorcik, Molly Lipscomb, and Aaditya Mattoo. 2012. Services Reform and Manufacturing Performance: Evidence from India. World Bank Policy Research Working Paper 5948. Washington: World Bank.

Arnold, Jens, Beata Javorcik, and Aaditya Mattoo. 2011. Does Services Liberalization Benefit Manufacturing Firms?: Evidence from the Czech Republic. Journal of International Economics 85, no. 1: 136-146.

Borchert, Ingo, Batshur Gootiiz, and Aaditya Mattoo. 2014. Policy Barriers to International Trade in Services: Evidence from a New Database. The World Bank Economic Review 28, no. 1: 162-188.

Calvo-Pardo, Hector, Caroline Freund, and Emanuel Ornelas. 2011. The ASEAN Free Trade Agreement: Impact on Trade Flows and External Trade Barriers. In Costs and Benefits of Regional Economic Integration in Asia, ed. Robert Barro and Jong-Wha Lee. Oxford: Oxford University Press.

Cebula, Richard, Joy Mazumdar, and Usha Nair-Reichert. 2011. US Trade and Access to Trade Facilitating Services in Partner Countries: An Empirical Analysis. Journal of Economic Integration 26, no. 3: 411-432.

Chadha, Rajesh, Drusilla Brown, Alan Deardorff, and Robert Stern. 2000. Computational Analysis of the Impact on India of the Uruguay Round and the Forthcoming WTO Trade Negotiations. Mimeo, University of Michigan.

Drysdale, Peter, and Ross Garnaut. 1982. Trade Intensities and the Analysis of Bilateral Trade Flows in a Many-Country World: a Survey. Hitotsubashi Journal of Economics 22, no. 2: 62-84.

Estevadeordal, Antoni, Caroline Freund, and Emanuel Ornelas. 2008. Does Regionalism Affect Trade Liberalization toward Nonmembers? The Quarterly Journal of Economics 123, no. 4: 1531-1575.

Fukase, Emiko. 2013. Export Liberalization, Job Creation, and the Skill Premium: Evidence from the US-Vietnam Bilateral Trade Agreement (BTA). World Development 41, 317 337. 
Fukase, Emiko, and Will Martin. 2001. A Quantitative Evaluation of Vietnam's Accession to the ASEAN Free Trade Area. Journal of Economic Integration 16, no. 4: 545-567.

Fukase, Emiko, and Will Martin. 2000. The Effects of the United States Granting MFN Status to Vietnam. Weltwirtschaftliches Archiv 136, no. 3: 539-559.

Fukase, Emiko, and L. Alan Winters. 2003. Possible Dynamic Effects of AFTA for the New Member Countries. The World Economy 26, no. 6: 853-871.

Fukui, Tani, and Christine McDaniel. 2010. Services Liberalization and Computable General Equilibrium Modeling: Beyond Tariff Equivalents. Journal of International Commerce and Economics. Washington: United States International Trade Commission.

Gervais, Antoine, and Bradford Jensen. 2013. Are Services Tradable? Evidence from US Microdata. Mimeo, Georgetown University.

Guimbard, Houssein, Sébastien Jean, Mondher Mimouni, and Xavier Pichot. 2012. MAcMapHS6 2007, an Exhaustive and Consistent Measure of Applied Protection in 2007. International Economics 130, 99-121.

Hoda, Anwarul, and Ashok Gulati. 2014. Towards India-US FTA in Agriculture. Mimeo.

Hoekman, Bernard, and Carlos Primo Braga. 1997. Protection and Trade in Services: a Survey. Open Economies Review 8, no. 3: 285-308.

Hertel, Thomas. 1996. Global Trade Analysis: Modeling and Applications. New York: Cambridge University Press.

Hertel, Thomas, David Hummels, Maros Ivanic, and Roman Keeney. 2007. How Confident Can We Be of CGE-based Assessments of Free Trade Agreements? Economic Modelling 24, no. 4: 611-635.

Hufbauer, Gary, Jeffrey Schott, and Woan Wong. 2010. Figuring Out the Doha Round, no. 91. Washington: Peterson Institute for International Economics.

Huff, Karen, and Thomas Hertel. 2000. Decomposing Welfare Changes in the GTAP Model. GTAP Technical Paper 5, Purdue University.

Jafari, Yaghoob, and David Tarr. 2014. Estimates of Ad Valorem Equivalents of Barriers against Foreign Suppliers of Services in Eleven Services Sectors and 103 countries. World Bank Policy Research Working Paper 7096. Washington: World Bank.

Konan, Denise Eby, and Keith Maskus. 2006, Quantifying the Impact of Services Liberalization in a Developing Country. Journal of Development Economics 81, no. 1: 142-162. 
Laborde, David, Will Martin, and Dominique van der Mensbrugghe. 2011. Measuring the Benefits of Global Trade Reform with Optimal Aggregators of Distortions. World Bank Policy Research Working Paper 5665. Washington: World Bank.

Lawrence, Robert, and Rajesh Chadha. Should a US-India FTA Be Part of India's Trade Strategy? In India Policy Forum 2004. ed._Suman Bery, Barry Bosworth and Arvind Panagariya. Brookings Institution Press.

Petri, Peter, Michael Plummer, and Fan Zhai. 2012. The Trans-Pacific Partnership and AsiaPacific Integration: A Quantitative Assessment. Policy Analyses in International Economics 98. Peterson Institute for International Economics and East-West Center.

Robinson, Sherman, Zhi Wang, and Will Martin. 2002. Capturing the Implications of Services Trade Liberalization. Economic Systems Research 14, no. 1: 3-33.

Salter, Wilfred. 1959. Internal and External Balance: the Role of Price and Expenditure Effects. Economic Record 35, no. 71: 226-238.

Topalova, Petia. 2010. Factor Immobility and Regional Impacts of Trade Liberalization: Evidence on Poverty from India. American Economic Journal: Applied Economics 2, no. 4: 1-41. 
Appendix Table A Change in trade (imports plus exports) by scenarios and by regions (\$ million)

\begin{tabular}{|c|c|c|c|c|c|c|c|c|c|c|c|c|c|c|c|c|}
\hline$\underline{\text { Scenario }}$ & Baseline & $\underline{\text { US-TPP }}$ & US-EU27 & $\begin{array}{l}\underline{\mathrm{A} 3 \mathrm{~T}} \\
\underline{\text { India- }} \\
\underline{\text { EU27 }}\end{array}$ & $\begin{array}{l}\text { A4T } \\
\frac{\text { India- }}{\text { ASEAN }} \\
\end{array}$ & $\begin{array}{c}\frac{\mathrm{A} 5 \mathrm{~T}}{\mathrm{~A} 1 \mathrm{~T}+\mathrm{A} 2 \mathrm{~T}} \\
+\mathrm{A} 3 \mathrm{~T}+\mathrm{A} 4 \mathrm{~T}\end{array}$ & $\begin{array}{r}\text { B1T } \\
\stackrel{\text { A1T }}{+ \text { Indi-US }} \\
\end{array}$ & $\begin{array}{c}\mathrm{B} 2 \mathrm{~T} \\
+\frac{\mathrm{A} 2 \mathrm{~T}}{+ \text { India-US }} \\
\end{array}$ & $\begin{array}{c}\text { B3T } \\
+\frac{\mathrm{A} 3 \mathrm{~T}}{+ \text { India-US }} \\
\end{array}$ & $\begin{array}{c}\text { B4T } \\
+\frac{\mathrm{A} 4 \mathrm{~T}}{+ \text { India-US }}\end{array}$ & $\begin{array}{c}\text { B5T } \\
\stackrel{A 5 T}{+ \text { India-US }} \\
\end{array}$ & $\begin{array}{l}\frac{\mathrm{C} 1 \mathrm{~T}}{\mathrm{~B} 1 \mathrm{~T}} \\
+\frac{\operatorname{India}}{\mathrm{MFN}}\end{array}$ & $\begin{array}{l}\frac{\mathrm{C} 2 \mathrm{~T}}{\mathrm{~B} 2 \mathrm{~T}} \\
+\frac{\text { India }}{\mathrm{MFN}}\end{array}$ & $\begin{array}{l}\frac{\mathrm{C} 3 \mathrm{~T}}{\mathrm{~B} 3 \mathrm{~T}} \\
+\frac{\operatorname{India}}{\mathrm{MFN}}\end{array}$ & $\begin{array}{l}\frac{\mathrm{C} 4 \mathrm{~T}}{\mathrm{~B} 4 \mathrm{~T}} \\
+\frac{\operatorname{India}}{\mathrm{MFN}}\end{array}$ & $\begin{array}{l}\frac{\mathrm{C} 5 \mathrm{~T}}{\mathrm{~B} 5 \mathrm{~T}} \\
+\frac{\mathrm{India}}{\mathrm{MFN}}\end{array}$ \\
\hline United States & 21872 & 36107 & 62169 & -3121 & -1320 & 93011 & 57606 & 83337 & 15642 & 18846 & 110099 & 42038 & 67983 & 4802 & 5429 & 101052 \\
\hline India & 19105 & -965 & -1004 & 47844 & 37226 & 76279 & 17801 & 17581 & 63026 & 54229 & 90143 & 136679 & 136378 & 145519 & 141673 & 147027 \\
\hline Australia/New Zealand & -480 & 2168 & -641 & -971 & -611 & 44 & 1684 & -1226 & -1443 & -1159 & -281 & 4494 & 1569 & 2180 & 2101 & 3684 \\
\hline Canada/Mexico & -475 & 24232 & -2970 & -744 & 32 & 20292 & 23681 & -3480 & -1266 & -527 & 19760 & 24264 & -2991 & -296 & -203 & 20696 \\
\hline EU 27 & -7018 & -13765 & 23864 & 48399 & -2810 & 50326 & -20714 & 11259 & 34837 & -15144 & 43089 & -8641 & 23072 & 1687 & -1769 & 15696 \\
\hline Chile/Peru & -95 & 1673 & -262 & -212 & -85 & 1096 & 1551 & -686 & -628 & -513 & 993 & 1278 & -956 & -737 & -723 & 934 \\
\hline Rest of LAC & -662 & -749 & -1665 & -614 & -493 & -3361 & -1383 & -1461 & -355 & -278 & -3879 & -747 & -832 & 614 & 684 & -2680 \\
\hline Japan & -594 & -608 & -1188 & -810 & -602 & -3350 & -1193 & -1823 & -1386 & -1247 & -3838 & 1109 & 476 & 1371 & 1402 & -627 \\
\hline China & -1765 & -1585 & -2617 & -3315 & -1954 & -9223 & -3285 & -4278 & -4743 & -3587 & -10550 & -1987 & -3002 & -1217 & -680 & -5549 \\
\hline MENA & -2193 & -2152 & -2596 & -4407 & -1630 & -10426 & -4309 & -5237 & -6633 & -4149 & -11980 & 872 & -72 & 2003 & 2378 & -2296 \\
\hline ASEAN (no TPP) & -618 & -826 & -893 & -1000 & 10020 & 6694 & -1423 & -1617 & -1649 & 9135 & 6094 & 2413 & 2213 & 2969 & 5005 & 3237 \\
\hline SAFTA & -339 & -445 & -325 & -457 & -247 & -1419 & -764 & -708 & -838 & -640 & -1711 & -1018 & -969 & -956 & -685 & -1636 \\
\hline ASEAN (TPP) & -767 & 11401 & -1118 & -1509 & 7124 & 14838 & 10455 & -2141 & -2422 & 5906 & 13930 & 10039 & -2482 & -1651 & 364 & 10163 \\
\hline SSA & -608 & -700 & -990 & -1115 & -659 & -3358 & -1296 & -1597 & -1622 & -1229 & -3790 & -450 & -757 & 62 & 161 & -1647 \\
\hline Others & -2939 & -2355 & -5802 & -1996 & -1797 & -12075 & -5255 & -8400 & -4170 & -4325 & -14298 & -144 & -3313 & 1379 & 1937 & -7486 \\
\hline
\end{tabular}

Source: Authors simulation results.

Notes: The change in trade reflects relative to the base year 2007.

Scenarios A1T through C5T correspond to those in table 7b. 